\title{
PRAVNE POSLJEDICE PROPUŠTANJA ODGOVORA NA TUŽBU
}

Sažetak: Jedna od brojnih novina koju je donio Zakon o parničnom postupku Federacije BiH iz 2003. godine, u cilju povećanja učinkovitosti suđenja, jeste da je dostava tužbe i pozivanja tuženika da podnese odgovor na tužbu postao obvezni podstadij u fazi pripremanja glavne rasprave, dok je dostava odgovora na tužbu postala dužnost tuženika. Sud će primjerak potpune i uredne tužbe s prilozima dostaviti tuženiku radi podnošenja pisanog odgovora, a u pozivu će ga upozoriti na pravne posljedice propuštanja te radnje. Međutim, procesno pravo ne obvezuje nijednu stranku na određeno držanje u parnici, pa tuženik može po svom izboru biti aktivan i poduzimati parnične radnje odnosno protiviti se zahtjevu tužitelja, može priznati činjenične navode i zahtjeve svog protivnika ili ostati pasivan, odnosno braniti se propuštanjem poduzimanja parničnih radnji radi zaštite svojih interesa.

Cilj rada jeste analizirati institut odgovora na tužbu, a posebna je pozornost dana propuštanju parnične radnje podnošenja pisanog odgovora na tužbu, koja za posljedicu ima donošenje meritorne odluke - presude zbog propuštanja, kojom se zahtjev usvaja bez raspravljanja i dokazivanja. Istražuje se općenito pravna priroda presude zbog propuštanja, razmatraju se pretpostavke za njeno donošenje, te mogućnost njezina pobijanja. Prethodno će biti razmotren njezin povijesni razvoj. Ukazat će se, također, na rješenja u poredbenom pravu.

Ključne riječi: tužba, odgovor na tužbu, presuda zbog propuštanja, prijedlog za povrat, žalba 
KEVO, M., Pravne posljedice propuštanja odgovora na tužbu Zbornik radova Pravnog fakulteta Sveučilišta u Mostaru, br. XXVII., 2019., str. 84. - 120.

\section{Uvodne napomene}

Zakonom o parničnom postupku Federacije Bosne i Hercegovine ${ }^{1}$, Zakonom o parničnom postupku Republike Srpske ${ }^{2}$, Zakonom o parničnom postupku Brčko Distrikta ${ }^{3}$, te Zakonom o parničnom postupku pred Sudom Bosne i Hercegovine ${ }^{4} u$ odnosu na ranije ponuđena zakonska rješenja odgovora na tužbu uvedena su nova svojstva ovoga instituta, te uvjeti i posljedice koje su uz njega vezane. Predviđena je i nova vrsta odluke - presuda zbog propuštanja, koja je u uskoj vezi s odgovorom na tužbu jer se, uz ispunjenje ostalih procesnopravnih i materijalnopravnih pretpostavki, donosi zbog nepodnošenja odgovora na tužbu. Prema odredbi čl. 70. ZPP F $\mathrm{BiH}$ nakon prijema tužbe sa prilozima, tuženi je dužan najkasnije u roku od 30 dana dostaviti sudu pismeni odgovor na tužbu. Prilikom dostavljanja tužbe tuženom, sud će poučiti tuženog o ovoj obavezi, o tome što treba sadržati odgovor na tužbu i obavijestiti ga o posljedicama njegova nedostavljanja u određenom roku. ${ }^{5}$ Neki autori ${ }^{6}$ zastupaju mišljenje da podnošenja odgovora na tužbu nije dužnost, već pravo tuženika, nije obveza već ovlaštenje. Međutim, iz zakonske odredbe jasno je da je dužnost tuženika podnijeti odgovor na tužbu. Sud je dužan da, poštujući načela parničnog postupka, a među njima i načelo kontradiktornosti, omogući ravnopravan tretman stranaka i mogućnost da poduzimaju procesne radnje. ${ }^{7}$ Obveznim dostavljanjem tužbe s prilozima tuženom na odgovor udovo-

1 Zakon o parničnom postupku Federacije Bosne i Hercegovine, Službene novine Federacije Bosne i Hercegovine br.53/03., 73/05. i 19/06. - dalje, ZPP F BiH iz 2003. Zakon o izmjenama i dopunama ZPP F BiH (Službene novine F BiH, br. 98/15. - dalje Izmjene ZPP F BiH).

2 Zakon o parničnom postupku Republike Srpske, Službeni glasnik Republike Srpske, br. 58/2003., 85/03., 74/05., 63/07., 105/08, odluka US 45/09., odluka US 49/09. - dalje - ZPP RS. Zakon o izmjenama i dopunama ZPP RS, Službeni glasnik Republike Srpske, br. 6/13. - dalje Izmjene ZPP RS iz 2013. godine.

3 Zakon o parničnom postupku Brčko Distrikta, „Službeni glasnik Brčko Distrikta BiH“ br. 28/18. - dalje ZPP BD.

4 Zakon o parničnom postupku pred Sudom Bosne i Hercegovine, Službeni glasnik Bosne i Hercegovine, br. 36/04., 84//07.,58/13 i 94/16 - dalje ZPP BiH.

$5 \quad$ Istovjetna je odredba čl. 70. ZPP RS. Istovjetna je odredba čl. 193. ZPP BD, te čl. 37. ZPP $\mathrm{BiH}$.

6 Vidi Cimirotić, M., „Odgovor na tužbu - dužnost ili pravo, od prijema ili od dostave tužbe?", Anali pravnog fakulteta univerziteta u Zenici, broj 6., godina 3., studeni 2010., str. 149. - 178.

7 Tako Janevski, A., Rakočević, M., „Ovlašćenje ili dužnost stranaka da raspravljaju pred sudom, Posljedice pasivnosti stranaka u parničnom postupku“, zbornik radova Vladavina prava i pravna država u regionu, Istočno Sarajevo 2014, str. 339. - 358. Obveza suda je da strankama omogući korištenje procesnih ovlaštenja, a na njima je teret da li će takvu mogućnost koristiti. 
ljava se načelu kontradiktornosti. ${ }^{8}$ Tuženom je pružena mogućnost da se odbrani, a on sam odlučuje hoće li se odazvati pozivu i aktivno sudjelovati u postupku zbog zaštite svojih interesa. Ako se uredno pozvani tuženi ogluši na poziv suda, odnosno propusti poduzimanje parnične radnje dostave odgovora na tužbu, takvo postupanje neće spriječiti sud da dalje postupa, niti će takvim pasivnim držanjem spriječiti brzo i učinkovito rješavanje predmeta spora. ${ }^{9} \mathrm{U}$ ovom slučaju, sud usvaja tužbeni zahtjev tužitelja (donosi presudu zbog propuštanja), ako je to sam tužitelj predložio u tužbi, zasnivajući svoje uvjerenje samo na navodima aktivne stranke, tj. tužitelja, ne vodeći pri tome redovni postupak dokazivanja kako bi provjerio njihovu istinitost. Sud je jedino ovlašten ispitati je li tužbeni zahtjev očito neosnovan, odnosno je li tužbeni zahtjev očito protivan činjenicama navedenim u tužbi i jesu li činjenice na kojima se zasniva tužbeni zahtjev u suprotnosti s dokazima koje je sam tužitelj predložio ili s činjenicama koje su općepoznate.

\section{Odgovor na tužbu}

\subsection{Pojam, opća svojstva i povijesni prikaz}

Odgovor na tužbu (njem. Klagebeantworte) jest radnja tuženika kojom se očituje o procesnoj dopustivosti parnice odnosno o osnovanosti tužbenoga zahtjeva. ${ }^{10}$ Nakon primitka tužbe s prilozima, tuženik je dužan najkasnije u roku od 30 dana dostaviti sudu pismeni odgovor na tužbu (čl. 70. st. 1. ZPP F BiH). Ravnopravan položaj stranaka sa suprotnim interesima u postupku osigurava se tako da se svakoj od njih zajamči pravo na izjašnjenje o parničnim radnjama koje poduzima njezin protivnik. U tome leži suština načela obostranog saslušanja (načela kontradiktornosti), koje je sadržano u odredbi čl. 5. ZPP F BiH. Ova odredba predvi-

$8 \quad$ Kontradiktornost nije ništa drugo nego ostvarenje najvǎnijeg načela svakog ispravnog parničnog postupka, tj. načela saslušanja obadviju parničnih stranaka (audiatur et altera pars). Sastoji se u tome da se o svakoj činjenici, koja bi mogla biti važna za razjašnjenje ili rješenje nekog spornog pravnog odnosa, saslušaju obje parnične stranke. Vidi: Zuglia, S., Građanski parnični postupak FNRJ, Zagreb, 1957., (dalje - Zuglia), str.91.

9 Parnične stranke nisu dužne na određen način držati se u postupku, niti se na bilo kakvo držanje mogu prinuditi. Držanje stranaka je stvar dispozicije jer je njihovo pravo povrijeđeno ili ugroženo pa stranke biraju kako se ponašati u postupku. Sud i parnične stranke su glavni subjekti postupka kao odnosa procesnopravne prirode, koji se pokreće, razvija i okončava radnjama ovih subjekata. Vidi Keča, R., Građansko procesno pravo, Beograd, 2010., (dalje - Keča), str. 48.

10 Vidi Čizmić, J., Komentar zakona o parničnom postupku, drugo izmijenjeno i dopunjeno izdanje, Sarajevo, 2016., (dalje - Čizmić - Komentar), str. 271. 
đa da stranka ima pravo izjasniti se o prijedlozima i zahtjevima protivne stranke, a da je samo iznimno, kada je to zakonom određeno, sud ovlašten odlučiti o zahtjevu o kojem protivnoj stranci nije bila dana mogućnost izjašnjavanja. ${ }^{11} 12$

U pravnoj literaturi odgovor je na tužbu jednostrana defenzivna parnična radnja tuženog kojom na poziv suda ili po vlastitoj inicijativi iznosi svoj stav o zahtjevima istaknutima u tužbi i o procesnim pitanjima u vezi s tim zahtjevima. ${ }^{13}$ Odgovor na tužbu je parnična radnja tuženog kojom on izražava svoj stav prema tužbi. ${ }^{14}$ Mišljenja smo da bi prikladnija definicija bila da je to parnična radnja tuženog kojom on izražava svoj stav prema tužbi, jer ta radnja ne mora uvijek biti defenzivna. Tako tuženi u odgovoru na tužbu može priznati tužbeni zahtjev, izjasniti se o osnovanosti zahtjeva i navoda, o istinitosti činjenica navedenih u tužbi ili o vjerodostojnosti predloženih dokaza, te predložiti utvrđivanje činjenica koje mu idu u prilog. Kao procesni institut bio je normiran svakim zakonom o parničnom postupku koji je bio u primjeni na području BiH Zakonikom o sudskom postupku u građanskim parnicama (građanski parnični postupak) za Kraljevinu Srba, Hrvata i Slovenaca ${ }^{15}$, Zakonom o parničnom postupku iz 1958. Godine, ${ }^{16}$ Zakonom o parničnom postupku iz 1978. godine, ${ }^{17}$ Zakonom o parničnom po-

11 Tako Jakšić, A., Građansko procesno pravo, deveto izdanje, Beograd, 2017. (dalje - JAKŠIĆ) str. 196. Sud, po pravilu, ne može odlučivati o zahtjevu stranke, ako njezinom protivniku nije pružio mogućnost da se o tom zahtjevu izjasni.

12 Stranci nije uskraćena mogućnost raspravljanja pred sudom kad je sud nije saslušao zbog toga što se nije odazvala pozivu suda. (VS RH, Rev-615/98 od 16.01.2002., Informator, br. 5206., od 28.1.2004.), podatak kod V. Haubrich, „Presuda zbog propuštanja u parničnom postupku“, Zbornik radova Aktualnosti građanskog i trgovačkog zakonodavstva i pravne prakse, br. 10, Mostar 2012., (dalje - Haubrich), str. 400. - 411.

13 Vidi Triva, S., Rječnik građanskog procesnog prava, Informator, Zagreb, 1968., str. 200.

14 Vidi, Stanković, G., Građansko procesno pravo, Zavod za udžbenike i nastavna sredstva, Beograd, 1989. (dalje - Stanković), str. 286.

15 Zakonik o sudskom postupku u građanskim parnicama (građanski parnični postupak, dalje - Grpp) od 13.srpnja 1929. godine, osim njegove sedme glave, dobio je obveznu snagu 1. siječnja 1932. godine, izuzev područja Apelacionih sudova u Beogradu i Skoplju i Velikog suda u Podgorici; u tim područjima ovaj Zakonik dobiva obveznu snagu dana 1. siječnja 1933.godine. Sedma glava Zakonika o siromaškom pravu dobiva obveznu snagu za cijelu državu na dan obnarodnjavanja zakona. Vidi: Uvodni Zakon za Zakonik o sudskom postupku u građanskim parnicama (građanski parnični postupnik) od 9. srpnja 1930. br. 68.509-3-78 (Službene novine 30/7. 1930. br. 171-LXV).

16 Prvi zakon o parničnom postupku u FNRJ (dalje - ZPP 58) donesen je 8. 12. 1956, objavljen je u Službenom listu FNRJ, br. 4/57. Zakon je nekoliko puta mijenjan i dopunjavan: SL FNRJ 52/61., SL FNRJ 12/65., 1/71., 23/72 I 6/74.

17 Zakon o parničnom postupku, proglašen Ukazom Predsjednika Republike, od 24. 12. 1976. godine (dalje - ZPP 78) objavljen je u Službenom listu SFRJ br. 4. od 14. 1. 1977. 
stupku Federacije Bosne i Hercegovine iz $1998^{18}$ te Zakonom o parničnom postupku F BiH iz 2003. godine.

Prema odredbi $₫ 338$. Grpp ako prema rezultatu prvog ročišta bude potrebno odrediti usmenu spornu raspravu, sudac, kojem je povjereno držanje prvog ročišta, odmah će na ročištu naložiti tuženiku zaključkom ${ }^{19}$ da odgovori na tužbu i odrediti mu rok za predaju odgovora, koji će odmjeriti prema okolnostima pojedinog slučaja, ali ne duže od četiri tjedna. Protiv tog zaključka nije bio dopušten pravni lijek. Prvo će se ročište odrediti tako da između dostave tužbe i ročišta rok otprilike bude petnaest dana. Pri tome će se paziti na vrijeme koje je vjerojatno potrebno za dostavljanje ( $\$ 326$. st. 1. Grpp). Sadržaj odgovora bio je predviđen zakonom. Odgovor na tužbu morao je sadržavati određenu izjavu i prijedlog u pogledu samog glavnog pitanja, odnosno priznaje li tuženik u cijelosti ili djelomično tužbeni zahtjev ili predlaže da se tužitelj odbije sa svojim tužbenim zahtjevom, zatim da se tuženik izjasni o istinitosti ili neistinitosti tužiteljevih navoda, o dopustivosti ili nedopustivosti ponuđenih dokaznih sredstava, da navede sve materijalne i procesne prigovore za koje je dužan ponuditi potrebne dokaze. Nadalje, ako odgovor na tužbu nije bio podnesen na vrijeme tuženiku se nije dopuštalo da se upušta u raspravu o glavnoj stvari nego samo da se raspravlja o eventualnim prijavljenim prigovorima na prvom ročištu, koji sprječavaju vođenje parnice - da redoviti put nije dopušten, da sud nije nadležan, da spor već teče ili da je stvar pravomoćno presuđena. Na tužbu se odgovaralo pripremnim podneskom..$^{20} \mathrm{Tim}$ podneskom tuženik je iznosio svoju obranu od prijedloga i navoda sadržanih u tužbi. Ako je tuženik podnio odgovor na tužbu poslije zakonom određenog roka, sud ga je odbacivao po službenoj dužnosti. ${ }^{21}$

godine. Ispravak Zakona o parničnom postupku objavljen je u Službenom listu SFRJ, br. 36 od 15. 7. 1977., Zakonom o dopuni Zakona o parničnom postupku od 25. 6. 1980 koji je objavljen u Službenom listu SFRJ, br. 36/80 od 27. 6. 1980., Zakon je dopunjen novim članom 178 a. Zatim je zakon još nekoliko puta izmjenjen i dopunjen: SL SFRJ 69/82, SL SFRJ 58/84, SL SFRJ 74/87, SL SFRJ 57/89 i SL SFRJ 27/90. Službene novine Federacije BiH, br. 42/98 od 03. 11. 1998. godine (dalje - ZPP 98).

"Zaključak, kojim se tuženiku koji je prisutan na prvom ročištu, nalaže da odgovori na tužbu i određuje rok za to, ima se objaviti i unijeti u raspravni zapisnik s označenjem roka za odgovor na tužbu- $\$ 208$ br. 3 Gr. p. p. (\$271 J. gr. p. p.). Otpravci ovog zaključka neće se dostaviti strankama ( $\$ 79$ posljednji stav Zak. o ustrojstvu sudova). Podatak preuzet od Najman, G., Komentar građanskog parničnog postupka, Štamparija Planeta, Beograd, 1935., (dalje - Najman - Komentar), str. 847.

Vidi Aranđelović, D., Građansko procesno pravo Kraljevine Jugoslavije, druga knjiga, za potrebe slušatelja Pravnog fakulteta, Beograd, 1933., (dalje - Aranđelović) str. 35. i 36.

Najman - Komentar, o. c., str. 1093.; usp. Goršić, F., Komentar građanskog parničnog postupka, II, Geca Kon, Beograd, 1933., (dalje - Goršić - Komentar), str. 242. 
U ZPP 58, ZPP 78 i ZPP F BiH 98 institut odgovora na tužbu bio je normiran na istovjetan način. Ako predsjednik vijeća smatra da se na osnovu tužbe može dalje postupati, zakazat će, po pravilu, pripremno ročište i naredit će da se primjerak tužbe dostavi tuženiku (čl. 273 ZPP 58). ${ }^{22}$ Prije zakazivanja pripremnog ročišta predsjednik vijeća može zatražiti od tuženog da podnese odgovor na tužbu, ako bi zbog složenosti spora ili zbog većeg broja zahtjeva stavljenih u tužbi bilo svrsishodno da se tuženi pismeno izjasni o navodima u tužbi. Izuzetno, s obzirom na posebne okolnosti slučaja, ovaj rok može iznositi i do trideset dana. Ako tuženi podnese odgovor na tužbu, predsjednik će vijeća ocijeniti je li, s obzirom na prijedloge i navode stranaka, potrebno zakazati pripremno ročište ili se odmah može zakazati ročište za glavnu raspravu. Ako tuženi u određenome roku ne podnese odgovor na tužbu, predsjednik vijeća zakazat će pripremno ročište ili ročište za glavnu raspravu. Rok za dostavu odgovora na tužbu je sudski rok čije je maksimalno trajanje bilo određeno zakonom, i to 15 dana od dostave tužbe, s time da je iznimno s obzirom na osobite okolnosti slučaja taj rok mogao biti i do 30 dana, a određivao ga je predsjednik vijeća. ${ }^{23}$ Odgovor na tužbu trebao je sadržavati izjašnjenje tuženika o navodima iz tužbe, posebno o istinitosti činjenica navedenih u tužbi ili vjerodostojnosti predloženih dokaza, te je tuženik uz odgovor trebao predložiti i dokaze potrebne radi utvrđivanja činjenica koje je iznio u odgovoru. Tuženi je u odgovoru također mogao isticati procesne i materijalno-pravne prigovore, odnosno incidentalne zahtjeve procesne naravi kao npr. zahtjev za izuzeće suca, zahtjev za osiguranje parničnih troškova, zahtjev za oslobađanje od plaćanja troškova postupka i sl. Tuženi može pismeno odgovoriti

22

23

Istovjetna je odredba čl. 284. ZPP 78 i čl. 265. ZPP F BiH 98.

Prema stajalištu starije sudske prakse, rok za davanje odgovora na tužbu nije se računao od dana kada je tuženik ovlastio svog punomoćnika, nego od dana dostave tužbe (VSV, Gž-714/57, podatak kod Dika, M., Čizmić, J., „Komentar Zakona o parničnom postupku Federacije Bosne i Hercegovine“, OSCE - Ured za demokratizaciju, Sarajevo, 2000., (dalje - Dika - Čizmić), str. 477.). Nastupala je zakonska presumpcija povlačenja tužbe u privrednom sporu ako tužitelj izostane s dva ročišta za glavnu raspravu, na koja je bio uredno pozvan, pa i kad od primitka poziva do održavanja ročišta nije održan rok od osam dana. Jer ako stranci nije bio ostavljen rok od osam dana za pripremanje ona je trebala doći na ročište i tražiti odgodu ročišta, ako je to potrebno. Samo zbog toga što stranci nije ostavljen rok od osam dana od dana primitka poziva, dostava poziva nije bila neuredna (VS FBiH, Pž -177/97, od rujna 1997. godine, podatak kod Dika - Čizmić, str. 477). Usp. M. Janković, Ž. Janković, H. Karamarković, D. Petrović, Komentar zakona o parničnom postupku, drugo dopunjeno izdanje, Suvremena administracija, Beograd, 1987. (dalje - Janković); Stranke su dužne da dođu na ročište i ako između uručenog poziva i dana ročišta nema osam dana. (Vrhovni sud Vojvodine, Gž 99/58). Stranka nije uredno pozvana ako joj nije ostavljen rok od osam dana od prijema poziva do ročišta za glavnu raspravu. (Viši privredni sud u Sarajevu, Sl -477/75), str. 345. 
na tužbu i ako mu sud to nije naložio. U postupku u privrednim sporovima uvijek će se tužba dostaviti tuženiku na odgovor (čl. 486. st.1. ZPP 98).

Prema citiranim odredbama zaključuje se da je sud imao dužnost dostaviti tužbu tuženiku, ali da je pozivanje tuženika da dostavi odgovor na tužbu prema odredbama Grpp ovisilo od ishoda na prvom ročištu, dok je prema odredbama ZPP 58, ZPP 78 i ZPP F BiH 98, osim u privrednim sporovima, ono bilo fakultativnog karaktera. Ako je prema odredbama Grpp sud naložio tuženiku da podnese odgovor na tužbu, on je imao dužnost odgovoriti. Nepodnošenje odgovora imalo je za posljedicu donošenje presude zbog propuštanja, ako bi tužitelj predložio njeno donošenje.

S druge strane, prema odredbama ZPP 58, ZPP 78 i ZPP F BiH 98, za tuženika koji ne dostavi odgovor na tužbu nisu nastupale nikakve procesne posljedice, niti je mogao biti prekludiran u pogledu poduzimanja bilo koje parnične radnje. Međutim, iako dostava odgovora na tužbu nije bila obvezna radnja tuženika, njenim poduzimanjem tuženik je mogao stvoriti određene procesne prednosti. Tako se protiv tuženika koji je u odgovoru na tužbu osporio tužbeni zahtjev nije mogla donijeti presuda zbog izostanka. ${ }^{24}$ Tuženik je mogao, ali nije morao dostaviti odgovor na tužbu, a mogao ga je dostaviti i ako mu sud nije to naložio, što upućuje na zaključak da je dostava odgovora na tužbu bila mogućnost/pravo tuženika, ali ne i dužnost.

\subsection{Obveznost odgovora na tužbu}

U cilju povećanja učinkovitosti suđenja, unaprjeđenja koncentracije u postupanju i prikupljanju procesne građe ZPP F BiH iz 2003. godine uvodi obvezu suda da tužbu s prilozima dostavi na odgovor tuženom u roku od 30 dana od dana primitka potpune i ispravne tužbe u sudu i dužnost tuženika da u roku od 30 dana od prijema tužbe s prilozima dostavi sudu pismeni odgovor na tužbu (čl. 69. i 70. st.1.ZPP-a F BiH). ${ }^{25}$ Pasivno držanje tuženog za koje zakon ne veže nikakve procesne posljedice može usporiti tijek parničnog postupka, a sud je dužan postupak provesti bez odugovlačenja i sa što manje troškova, te onemogućiti svaku zloupotrebu prava koja strankama pripadaju u postupku (čl. 10. ZPP $\mathrm{F} \mathrm{BiH).} \mathrm{Uvođenjem} \mathrm{ovih} \mathrm{obveza} \mathrm{osigurava} \mathrm{se} \mathrm{bolje} \mathrm{ostvarenje} \mathrm{prava} \mathrm{na} \mathrm{pravično}$ suđenje zajamčeno članom 6 . stavka 1 . Konvencije za zaštitu ljudskih prava i te-

\footnotetext{
$24 \quad$ Vidi Dika - Čizmić, o. c., str. 476.

25 Istovjetne su odredbe čl. 69. i 70. st.1. ZPP RS, čl.182. i 183. st. 1. ZPP BD, te čl. 36. i 37. st. 1. $\mathrm{ZPP} \mathrm{BiH}$.
} 
meljnih sloboda Vijeća Europe ${ }^{2627}$ jer je osigurana procesna ravnopravnost (equality of arms, ,jednakost oružja”), koja nije postojala po ranijim zakonima, kao jedna od ključnih garancija pravičnosti sudskog postupka. Nadalje, obveznim dostavljanjem tužbe s prilozima tuženom na odgovor udovoljava se načelu kontradiktornosti, koje se zajedno s načelom procesne ravnoteže i načelom javnosti u postupanju i odlučivanju nalazi u samom središtu pojma pravičnog (fair) suđenja. Načelo „jednakosti oružja“ je, u smislu procesne ravnoteže među strankama, uvedeno i potvrđeno u sudskoj praksi Europskog suda za ljudska prava u Strasbourgu $^{28}$ kao osnovni element pojma, odnosno prava na pravični postupak..$^{29}$ Ono nužno obuhvaća razumnu mogućnost stranaka da u postupku brani svoja prava pod uvjetima koji ga ne stavljaju u bitno nepovoljniji položaj u odnosu na njezinog protivnika.

\subsection{Sadržaj odgovora na tužbu}

Odredbom čl. 71. ZPP F BiH ${ }^{30}$ propisan je obvezni sadržaj odgovora na tužbu. Tako će u odgovoru na tužbu tuženik istaknuti moguće procesne prigovo-

$26 \quad$ Konvencija za zaštitu ljudskih prava i temeljnih sloboda Vijeća Europe (u daljnjem tekstu - Konvencija), kao temeljni pravni instrument zaštite ljudskih prava, usvojena je 4. studenoga 1950. u Rimu, a stupila je na snagu 3. rujna 1953.

27 Članak 6. stavak 1. Konvencije propisuje pravo na suđenje u razumnom roku odredbom koja glasi: „Prilikom utvrđivanja građanskih prava i obveza ili osnovanosti bilo kakve krivične optužbe, svatko ima pravo na pravično suđenje i javnu raspravu u razumnom roku pred nezavisnim i nepristranim, zakonom ustanovljenim sudom..."

Konvencijom, odnosno Protokolom broj 11 uspostavljen je Europski sud za ljudska prava u Strasbourgu (u daljnjem tekstu - Europski sud) koji je isključivo odgovoran za interpretaciju Konvencije te stoga, iako je Konvencija jedan od najvažnijih dokumenata za zaštitu ljudskih prava u Europi, značaj Konvencije ne proizlazi iz samog teksta, nego iz prakse Europskog suda koji joj je osigurao vodeću ulogu u definiranju suvremenih standarda zaštite ljudskih prava u europskim državama. Vidjeti članak 46. st 1. Konvencije.

Načelo jednakosti oružja se kao sredstvo ostvarivanja pravičnosti najprije pojavilo u jednom mišljenju Europske komisije 1959. u građanskom predmetu Europske komisije za ljudska prava Swabowicz protiv Švedske, 30. lipnja 1959., req.434/58, Ann II, str. 355, a zatim 1962. godine i u kaznenom predmetu Ofner i Hopfinger protiv Austrije, odluka, 23. studeni 1962., br. 524/59, 617/59., gdje se Europska komisija za ljudska prava precizno očitovala o odnosu između jednakosti oružja i pravičnog postupka, te utvrdila da opća odredba šireg dosega koja se odnosi na pravičan postupak iz člana 6. stavak 1 . Konvencije obuhvaća pojam jednakosti oružja. Podatak kod Ivičević, K., E., „Načelo jednakosti oruža kao konstitutivni element pravo na pravični kazneni postupak iz članka 6. Europske konvencije za zaštitu ljudskih prava i temeljnih sloboda", Zbornik Pravnog fakulteta Zagreb, 57, (4- 5) , 2007., str. 761. - 788.

$30 \quad$ Istovjetne su odredbe čl. 71. ZPP RS, čl. 184. ZPP BD, te čl. 38. ZPP BiH. 
re tj. prigovore kojima se osporava dopuštenost tužbe, očitovati se priznaje li ili osporava postavljeni tužbeni zahtjev. Odgovor na tužbu je podnesak pa treba sadržati i podatke koji su propisani za svaki podnesak i to: oznaku suda, ime i prezime odnosno naziv pravne osobe, prebivalište ili boravište odnosno sjedište stranaka, njihovih zakonskih zastupnika ili punomoćnika, ako ih imaju, predmet spora, sadržaj izjave i potpis podnositelja. Poštujući načelo ekonomičnosti i djelotvornosti odgovor na tužbu u kojem tuženi osporava tužbeni zahtjev mora sadržavati i razloge iz kojih se tužbeni zahtjev osporava, činjenice na kojima tuženi zasniva svoje navode i dokaze kojima se utvrđuju te činjenice (čl. 15. Izmjena ZPP F BiH). Prema ZPP F BiH iz 2003. godine odredbom čl. 71. st. 2. bilo je propisano da ako tuženik osporava tužbeni zahtjev, odgovor na tužbu mora sadržavati i razloge iz kojih se tužbeni zahtjev osporava, činjenice na kojima tuženi zasniva svoje navode i dokaze kojima se utvrđuju te činjenice, te pravnu osnovu za navode tuženika. Međutim, kako je čl. 8. Izmjena ZPP F BiH izmijenjen obvezan sadržaj tužbe, te određeno da pravna osnova ne mora biti osnovni element tužbe, podrazumijeva se da je i u odnosu na odgovor na tužbu urađena ista promjena, u smislu da ni odgovor na tužbu više ne mora sadržavati pravnu osnovu. Kada utvrdi da je odgovor na tužbu nerazumljiv ili nepotpun, sud će radi otklanjanja tih nedostataka vratiti tuženiku odgovor na tužbu radi ispravke ili dopune, uz navode što treba ispraviti ili dopuniti i odrediti mu rok za ispravku ili dopunu podneska, koji ne može biti duži od osam dana (čl. 73. ZPP F BiH). Ukoliko odgovor na tužbu bude odbačen ili povučen u skladu s čl. 336. st. 3. ZPP F BiH tj. ako bude vraćen bez ispravke ili dopune ili ako ne bude vraćen sudu u roku koji je odredio za ispravku i dopunu, smatrat će se da tuženi nije dao odgovor na tužbu (čl. 16. Izmjena ZPP F BiH). ${ }^{31}$ Odredbom čl. 16. Izmjena ZPP F BiH u čl. 73. ZPP F BiH 2003. dodan je novi st. 2. koji glasi: „, Ukoliko odgovor na tužbu bude odbačen ili povučen u skladu s čl. 336. st. 3. ZPP F BiH smatrat će se da tuženi nije dao odgovor na tužbu". Ovom dopunom riješilo se sporno pravno pitanje oko mogućnosti donošenja presude zbog propuštanja. Pa tako, ukoliko tuženi podnese odgovor na tužbu, koji sukladno odredbama čl. 336.st. 3. ZPP F $\mathrm{BiH}$ bude odbačen kao neuredan ili nepotpun, smatrat će se da odgovor nije ni dostavljen, iz čega proizlazi donošenje presude zbog propuštanja. ${ }^{32}$

U tekstu koji slijedi analizirat će se posljedice koje su procesni zakoni normirali kao rezultat pasivnog držanja tuženika u postupku, koje sankcije pogađaju tuženika koji je propustio obraniti se od napada svoga parničnog protivnika, odnosno kako pasivnost tuženika u slučaju propuštanja podnošenja odgovora na tužbu utječe na

31 Istovjetne su odredbe čl.73. ZPP RS, čl.186. ZPP BD, te čl.40. ZPP BiH.

32 Vidi: Čizmić - Komentar, o. c., str. 276. 
daljnji tijek parnice, te uzročno-posljedični odnos odgovora na tužbu i presude zbog propuštanja.

\section{Posljedice nepodnošenja odgovora na tužbu}

Kad tuženi, kome je uredno dostavljena tužba u kojoj je tužitelj predložio donošenje presude zbog propuštanja, ne dostavi pismeni odgovor na tužbu u zakonskom roku, sud će donijeti presudu kojom se usvaja tužbeni zahtjev (presuda zbog propuštanja), osim ako je tužbeni zahtjev očito neosnovan (čl. 182. ZPP F BiH). ${ }^{33}{ }^{34}$ Poučavanje tuženog o sadržaju odgovora na tužbu i o posljedicama propuštanja dostavljanja odgovora predstavlja obveznu radnju suda prilikom dostave tužbe tuženiku na odgovor i uvjet su prema kojem se cijeni urednost uručenja tužbe na odgovor. Prema tome, kad se uredno pozvani tuženi ogluši na poziv suda, odnosno odluči braniti se propuštanjem, takvim pasivnim držanjem neće spriječiti brzo i učinkovito rješavanje spornog predmeta, već će spor biti riješen donošenjem meritorne odluke - presude zbog propuštanja, bez održavanja ročišta.

\section{Presuda zbog propuštanja}

\subsection{Presuda zbog propuštanja u pravu Kraljevine Jugoslavije}

Institut presude zbog propuštanja bio je predviđen Zakonikom o sudskom postupku u građanskim parnicama (građanski parnični postupak) za Kraljevinu Srba, Hrvata i Slovenaca (Grpp) od 1929. godine.

Odredbom iz st. 1 . $\$ 494$. Grpp bilo je predviđeno da ako tuženik ne preda na vrijeme odgovor na tužbu, tužitelj može predložiti da se o glavnoj stvari donese presuda zbog propuštanja. Da bi sud donio ovu presudu, trebala su biti ispunjena dva osnovna uvjeta. Prvi se odnosio na to da tuženik nije na vrijeme odgovorio na tužbu, a drugi da je tužitelj predložio donošenje ove presude, a svemu je prethodilo tzv. prvo ročište koje se održavalo pred predsjednikom vijeća ili pred

\footnotetext{
Istovjetne su odredbe čl.182. ZPP RS, čl. 295. ZPP BD, te čl. 149. ZPP BiH.

34 Ako tužbom nije predložena ta presuda, sud će nastaviti postupak, pa tuženik može na pripremnom ročištu ili na ročištu za glavnu raspravu izložiti odgovor na tužbu. Vidi Čizmić, J., Miljko, S., „O presudi zbog propuštanja sa posebnim osvrtom na pravne lijekove/ sredstva protiv te presude“, Pravna misao br. 1 - 2, Sarajevo, 2008. (dalje - Čizmić - Miljko), str. 36. -57.
} 
članom vijeća kojemu je to predsjednik naložio. Prvo je ročište određivano kako bi se pokušalo poravnanje, prijavili razni procesni prigovori, npr. nedopustivosti redovnog pravnog puta ili nenadležnosti suda, da već teče parnica ili da je stvar pravomoćno presuđena, kao i da se primi izjava imenovanog prethodnika (auktora). Na ovom ročištu sporna se stvar mogla završiti presudom na osnovu priznanja, na osnovu odricanja ili zbog izostanka, a tužitelju je, na njegov prijedlog, moglo biti dopušteno preinačenje tužbe. Ako prema rezultatu prvog ročišta bude potreba odrediti usmenu spornu raspravu, sudac će naložiti tuženiku da odgovori na tužbu i odrediti mu rok za predaju odgovora koji će odmjeriti prema okolnostima pojedinog slučaja, ali ne duži od četiri tjedna ( $\$ 338$. st. 1. Grpp). Dakle, sam rok za odgovor na tužbu nije bio zakonom precizno određen, već se radilo o sudskom roku koji se tuženiku određivao na prvom ročištu, a koji se iz opravdanih razloga mogao i produžiti. Tuženik je bio dužan u tom roku odgovoriti na tužbu.

Daljnji je postupak bio određen time je li na prvom ročištu iznesen koji od prigovora. U slučaju da je tuženik propustio blagovremeno predati pismeni odgovor na tužbu, nastupala je dvostruka kontumacija, jedna po službenoj dužnosti, a druga tek na prijedlog tužitelja. Po zakonu nastupa prekluzija, isključenje od usmene rasprave u dotičnom pravnom sporu, jer se ročište za usmenu raspravu određivalo samo ako se odgovor na tužbu podnese na vrijeme. ${ }^{35}$ Daljnja posljedica tog propuštanja, donošenje kontumacijske presude nije nastupala nikada po službenoj dužnosti, već uvijek samo na prijedlog tužitelja. Taj se prijedlog podnosio pismeno, i sudac koji je sproveo prvo ročište izriče po tom prijedlogu pismeno, bez određivanja ponovnog ročišta, kontumacijsku presudu - presudu zbog propuštanja na osnovu činjenica navedenih u tužbi, uzimajući u obzir i sudsku notornost, te dokaze koji su se već nalazili pred sudom. Presuda se trebala donijeti u roku od osam dana ${ }^{36}$ otkako je stigao prijedlog, te pismeno priopćiti strankama. ${ }^{37}$ Međutim, tako se postupalo samo kad na prvom ročištu nije bio iznesen nijedan prigovor.

Ako je tuženik na prvom ročištu istakao koji od procesnih prigovora, poput nedopustivosti redovnog pravnog puta ili nenadležnosti suda, da već teče parnica ili da je stvar pravomoćno presuđena, postupak se odvijao na drugačiji način i u tom su se slučaju razlikovale dvije procesne situacije. Prva je bila kad je bilo

$35 \quad$ Pošto je na vrijeme predan odgovor na tužbu, predsjednik vijeća kome je pravna stvar upućena, ako je predloženo, da se povede pripremni postupak ili ako on smatra da je takav postupak potreban ili cijelishodan, iznijet će pred vijeće da ono o tome odluči: u protivnom slučaju odredit će ročište za usmenu spornu raspravu.Vidi $\$$. 339. Grpp

$36 \$ 494$. Grpp

$37 \$ 511$. Grpp 
naređeno odvojeno raspravljanje o istaknutim prigovorima, a druga kad nije bila određena odvojena rasprava o prigovorima koji su bili istaknuti na prvom ročištu. U prvoj situaciji tužitelj je mogao poslije pravomoćnog odbijanja prigovora predložiti da se o glavnoj stvari donese presuda zbog propuštanja. Potpuno je drugačija situacija bila kad nije bila određena odvojena rasprava o istaknutim prigovorima. Tužitelj je prethodno mogao predložiti samo to da se odredi ročište za usmenu raspravu. U tom se slučaju usmena sporna rasprava ograničavala na iznesene prigovore. Ako se oni odbiju, odmah se po daljnjem prijedlogu tužitelja donosila presuda zbog propuštanja. Zakonom je precizno bilo određeno da ako tuženik dođe na određeno ročište, to ne smeta da se donese presuda zbog propuštanja, a njegovi usmeni navodi koji se tiču glavne stvari neće se uzimati u obzir pri donošenju presude. ${ }^{38}$ Ako je ročište bilo određeno po prijedlogu tužitelja, ročište će se održati i donijeti rješenje o prigovorima samo ako na ročište dođe tužitelj. Izostane li tužitelj od tog ročišta, neće se sprovoditi ni rasprava o prijavljenim prigovorima, niti će se donijeti presuda zbog propuštanja, nego će nastupiti mirovanje postupka. Ponovo određivanje ročišta može tražiti samo tužitelj, nakon što proteče rok mirovanja od tri mjeseca, dok tuženik ne može tražiti ni prvobitno ni ponovno da sud odredi ročište za pretres njegovih prigovora. ${ }^{39}$

Iz citiranih se odredbi zaključuje da je zakonodavac bio predvidio rješenje u slučaju da tuženi ne dostavi pismeni odgovor na tužbu, odnosno ako propusti da ga dostavi na vrijeme. Tada je sud, na prijedlog tužitelja, donosio presudu zbog propuštanja. Nadalje, zakonodavac je bio propisao i uvjete koji su bili potrebni da bi se ona mogla donijeti. Pored ova dva osnovna uvjeta (da tuženik nije na vrijeme odgovorio na tužbu i prijedlog tužitelja), sljedeći su uvjeti za njezino donošenje bili: da je izostala stranka uredno pozvana na ročište, da nisu postojale općepoznate činjenice da je stranka koja je izostala zbog prirodnog događaja ili zbog drugog neotklonjivog slučaja bila spriječena doći (iako je bila uredno pozvana), te ako stranka koja je pristupila ne može na ročištu ponuditi dokaz koji sud traži u pogledu okolnosti, koje se po službenoj dužnosti moraju uzeti u obzir. ${ }^{40}$

\subsection{Razdoblje od 1945. do 2003. godine}

Do donošenja ZPP-a 58, odnosno Zakona o ubrzanju parničnog postupka pred redovnim sudovima iz 1955. godine, sudovi su primjenjivali pravna pravila iz

\footnotetext{
$38 \$$ 494.st.3. Grpp

39 Vidi Culja, S., Građansko procesno pravo Kraljevine Jugoslavije, Geca Kon, Beograd, 1936. (dalje - CULJA), str. 608.
}

$40 \quad$ .498 Grpp 
Grpp ako odgovarajuća pravna materija nije bila regulirana novim pravnim propisima i ako su ta pravila bila u skladu s društvenim uređenjem tadašnje Jugoslavije. $^{41}$

Zakon o ubrzanju parničnog postupka pred redovnim sudovima iz 1955. godine $e^{42}$ bio je prvi procesni zakon prije donošenja ZPP 58. Imao je privremeni karakter jer je trebao riješiti brojna goruća pitanja parnične procedure do donošenja ZPP $58 .^{43}$ Zakonom o ubrzanju parničnog postupka bila je propisana presuda zbog izostanka, koja se mogla donijeti samo protiv izostalog tuženika, ali uz uvjet da činjenični navodi tužbe opravdavaju traženu pravnu zaštitu. Dakle, istim nije bila normirana presuda zbog propuštanja odgovora na tužbu.

Parnični postupak kodificiran je tek 1958. godine donošenjem ZPP 58. ZPP 58 ni ZPP 78 nisu normirali presudu zbog propuštanja odgovora na tužbu, već je istima, kao i Zakonom o ubrzanju parničnog postupka pred redovnim sudovima iz 1955., bila normirana druga kontumacijska odluka - presuda zbog izostanka. ZPP 58 i ZPP 78 ne prave razlike u pogledu pretpostavki za njeno donošenje. Ona se donosila kad tuženi ne dođe na pripremno ročište do njegova zaključenja, ili na prvo ročište za glavnu raspravu ako pripremno ročište nije održano, ili ako dođe na ova ročišta, a neće se upustiti u raspravljanje ili se udalji s ročišta, a ne os-

${ }^{41}$ Predsjedništvo Antifašističkog vijeća narodnog oslobođenja Jugoslavije (AVNOJ) na svojoj četvrtoj sjednici održanoj 3. veljače 1945. godine, na prijedlog Nacionalnog komiteta oslobođenja Jugoslavije, jednoglasno je usvojilo Prijedlog odluke o ukidanju i nevažnosti svih pravnih propisa donesenih od okupatora i njegovih pomagača za vrijeme okupacije, o važnosti odluka koje su za to vrijeme donesene, o ukidanju pravnih propisa koji su bili na snazi u vrijeme neprijateljske okupacije (Službeni list DFJ, broj 4/45). Predsjedništvo Narodne skupštine FNRJ je 23. listopada 1946. godine proglasilo Zakon o potvrdi i izmjenama Odluke o ukidanju i nevažnosti svih pravnih propisa donesenih od okupatora i njegovih pomagača za vrijeme okupacije, o važnosti odluka koje su za to vrijeme donesene, o ukidanju pravnih propisa koji su bili na snazi u vrijeme neprijateljske okupacije (Službeni list SNRJ, broj 86/46). Izmijenjena Odluka o ukidanju i nevažnosti pravnih propisa bivšeg prava dobila je naziv - Zakon o nevažnosti pravnih propisa donesenih prije 6. 4. 1941. godine i za vrijeme neprijateljske okupacije. Iako su Zakonom o nevažnosti bivšeg prava svi propisi koji su vrijedili do 6. 4. 1941. godine proglašeni nepostojećim, pa se prema tome nisu mogli ni primijeniti kao pozitivni propisi, u praksi sudova, s obzirom na velik broj pravnih praznina, nerijetko je bila primjena pravnih pravila sadržanih u predratnim pravnim propisima. Vidi Bevanda, M., Obveznopravno uređenje u Bosni i Hercegovini, Mostar, 2013., str. 79. -85 .

Zakon o ubrzanju parničnog postupka pred redovnim sudovima donesen je 25. 4. 1955. godine, objavljen u Službenom listu FNRJ, br. 19, od 4. 5. 1955. godine, a stupio na snagu 12. 5.1955. godine.

Usp. Čizmić - Komentar, o. c., str. 23.; Zuglia, S., „Zakon o ubrzanju parničnog postupka pred redovnim sudovima“, Naša zakonitost, 9, 1955., br. 6 - 7, str. 249. 
pori tužbeni zahtjev, te ako su ispunjeni i sljedeći uvjeti: ako je tuženi bio uredno pozvan, ${ }^{44}$ ako tužitelj predloži donošenje presude zbog izostanka, ako tuženi nije podneskom osporio tužbeni zahtjev, ako osnovanost tužbenog zahtjeva proizlazi iz činjenica navedenih u tužbi, ako činjenice na kojima se temelji tužbeni zahtjev nisu u protivnosti s dokazima koje je sâm tužitelj podnio ili s činjenicama koje su općepoznate, ako ne postoje općepoznate okolnosti iz kojih proizlazi da su tuženog spriječili opravdani razlozi da dođe na ročište. Presuda zbog izostanka nije mogla biti donesena i ako su bili ispunjeni prednji uvjeti, ako sud nađe da se radi o zahtjevima kojima stranke ne mogu raspolagati. ${ }^{45}$ Prema oba zakona protiv presude zbog izostanka bila je dopuštena žalba, s tim da se žalba nije mogla podnijeti zbog pogrešno ili nepotpuno utvrđenog činjeničnog stanja. ${ }^{46}$

Zaključuje se da je kod presude zbog izostanka uvjet za njezino donošenje nepostojanje osporavanja tužbenog zahtjeva, za razliku od presude zbog propuštanja gdje je uvjet propuštanje tuženog da u određenom roku podnese pismeni odgovor na tužbu. Osporavanje bi izostalo ako tuženi ne ospori tužbeni zahtjev u odgovoru na tužbu, ali kako odgovor na tužbu nije bio obvezna parnična radnja, tuženi je mogao osporiti tužbeni zahtjev i na ročištu, ako ne dođe na pripremno ročište ili na prvo ročište za glavnu raspravu, ili je došao na ročište, a nije se upustio u raspravljanje ili se udaljio s ročišta, a nije osporio tužbeni zahtjev.

Nakon osamostaljenja, Predsjedništvo BiH, na temelju Amandmana LI toč. 5. st. 3. na Ustav $\mathrm{BiH}$, na prijedlog Vlade $\mathrm{BiH}$, donijelo je Uredbu sa zakonskom snagom o preuzimanju i primjenjivanju saveznih zakona koji se u $\mathrm{BiH}$ primjenjuju kao republički zakoni. ${ }^{47}$ Tako je preuzet i primjenjivao se u BiH kao republički zakon i Zakon o parničnom postupku. Prvi zakon o parničnom postupku Federacije $\mathrm{BiH}$ donesen je 1998. godine. To je bio prvi propis kojim su se na prostoru F BiH cjelovito određivala pravila postupka na temelju kojih sudovi raspravljaju i odlučuju u sporovima iz osobnih i obiteljskih odnosa, iz radnih odnosa, te iz

44 Uz poziv mora biti dostavljena tužba s prilozima, a tuženi se mora upozoriti na zakonske posljedice izostanka s ročišta. Poziv za pripremno ročište i ročište za glavnu raspravu trebao je biti dostavljen strankama najmanje 8 dana prije ročišta jer se inače smatralo da strankama nije ostavljeno dovoljno vremena da se pripremi za raspravu. U praksi je bilo sporno da li je bilo moguće donijeti presudu zbog izostanka ako ovaj rok nije bio ispoštovan. U procesnoj znanosti prevladavalo je shvatanje da u tom slučaju nije bilo uvjeta za njezino izricanje, dok u sudskoj praksi nije bilo jedinstvenog stava oko toga. U nekim odlukama zauzimao se stav da je tuženi ipak trebao doći na ročište i tražiti odlaganje rasprave, jer će u protivnom nastupiti zakonske posljedice izostanka. Vidi „Zakon o parničnom postupku s komentarom“, Markičević, A., Nip Export-press, Beograd, 1977., str.150.

$45 \quad$ Vidjeti čl. 321. st.1. ZPP 58 odnosno čl. 332. st. st.1 i 3. ZPP 78.

$46 \quad$ Vidi čl. 342. st. 3. ZPP 58 odnosno čl. 353. st. 2. ZPP 78.

47 Službeni list BiH, broj 2/92 od 11. 4. 1992 godine. 
imovinskih i drugih građansko-pravnih odnosa fizičkih i pravnih osoba. ZPP F $\mathrm{BiH}$ iz 98. normirao je presudu zbog izostanka u odredbi čl. 314. koja je bila istog sadržaja kao i odredba čl. 332 ZPP 78.

\section{Presuda zbog propuštanja u važećem bosanskohercegovačkom parničnom pravu}

\subsection{Pojam i pravna priroda presude zbog propuštanja}

ZPP F BiH je u parnični postupak unio brojne promjene koje su imale za cilj povećati učinkovitost suđenja i izbjegavanje nepotrebnog odugovlačenja postupka. Jedan od novih instituta u našem građanskom procesnom pravu jest presuda zbog propuštanja. Ratio legis ove vrste presude je jačanje procesne discipline parničnih stranaka i ubrzanje postupka, tako da stranka koja pokušava propuštanjem rokova ili propuštanjem poštivanja procesnih obveza polučiti koristi pretrpi negativne posljedice. ${ }^{48} \mathrm{U}$ literaturi ima mišljenja da presuda zbog propuštanja (ogluhe) predstavlja ustvari presudu koju sud izriče protiv tuženoga, a zasniva je na činjenici da je tuženi priznao činjenične navode tužitelja na kojima zasniva tužbeni zahtjev. Smatra se da sud polazi od apsolutne presumpcije da je tuženi time što nije podnio odgovor na tužbu ustvari priznao činjenice na kojim je tužbeni zahtjev zasnovan. ${ }^{49}$ Presude zbog izostanka ili propuštanja, odnosno kontumacijske ili oglušne presude takve su sudske presude kod kojih činjenični navodi nisu utvrđeni ni priznanjem parničnih stranaka ni izvedenim dokazima, već se moraju smatrati istinitim samo zato što je protivna stranka propustila stanovitu procesnu radnju. ${ }^{50}$ Ona se temelji se na sistemu afirmativne litikontestacije, prema kojem se pasivnost stranke tumači kao suglašavanje s navodima protivnika (qui tacet consentire videtur). ${ }^{51}$ Svoje opravdanje nalazi u tome što se njome ne dopušta da potpuno pasivan stav tuženika usporava razvoj postupka dokazivanjem činjenica na kojima je tužbeni zahtjev zasnovan. ${ }^{52}$

$48 \quad$ Vidi Kulenović, Z., Mikulić, S., Milišić-Veličovski, S., Stanišić, J., Vučina, D., Komentar Zakona o parničnom postupku F BiH/RS, drugo izmijenjeno i dopunjeno izdanje, Mostar, 2011, (dalje - KULENOVIĆ), str. 358.

49 Tako Triva S., Dika, M., Građansko parnično procesno pravo, Narodne novine, Zagreb, 2004. (dalje - TRIVA - DIKA), str. 604.

$50 \quad$ Vidi Culja, o. c., str. 599.

$51 \quad$ Usp. Poznić, Građansko procesno pravo, Beograd, 1980. (dalje - POZNIĆ), str. 271. - 272.; Čalija, B., Omanović, S., Građansko procesno pravo, Sarajevo, 2000. (dalje - ČALIJA OMANOVIĆ) str. 264. - 256, TRIVA - DIKA, str. 604., 609. cija, Beograd, 2010. (dalje -Poznić - Rakić - Vodinelić), str. 368. 


\subsection{Pretpostavke za donošenje presude zbog propuštanja}

\subsubsection{Općenito}

Da bi se mogla donijeti presuda zbog propuštanja, pored postojanja općih pozitivnih ${ }^{53}$ odnosno nepostojanja općih negativnih procesnih pretpostavki, ${ }^{54}$ potrebno je ispuniti i neke posebne procesnopravne i materijalnopravne pretpostavke. Procesnopravne pretpostavke su: uredno dostavljena tužba tuženiku na odgovor, prijedlog tužitelja za donošenje presude zbog propuštanja istaknut u tužbi, propuštanje tuženika da u zakonskom roku dostavi sudu pismeni odgovor na tužbu i mogućnost raspolaganja tužbenim zahtjevom. Ove pretpostavke su u svim procesnim zakonima u $\mathrm{BiH}$ kumulativno propisane, što znači da moraju sve zajedno biti ispunjene..$^{55}$ Materijalnopravna pretpostavka je da tužbeni zahtjev nije očito neosnovan. Dakle, od njezina postojanja ovisi mogućnost usvajanja tužbenog zahtjeva presudom zbog propuštanja. U literaturi se smatra da postojanje ovog uvjeta ne utječe na dopuštenost suđenja, već samo na mogućnost donošenja presude određenog sadržaja, u konkretnom, presude kojom se usvaja tužbeni zahtjev. ${ }^{56}$ Ovakav stav je prihvatljiv, sud će svakako donijeti presudu, samo što će u situaciji kada je tužbeni zahtjev očito neosnovan donijeti presudu kojom se tužbeni zahtjev odbija.

I kada su ispunjene sve posebne pretpostavke za donošenje presude zbog propuštanja, sud je neće donijeti ako postoje okolnosti zbog kojih nije dopušteno donošenje meritorne odluke uopće. To su okolnosti na koje sud pazi ex officio tijekom cijelog postupka, kako kod donošenja kontradiktornih tako i kod donošenja presuda zbog propuštanja. Radi se o postojanju procesnih smetnji zbog kojih bi tužbu trebalo odbaciti, a to su ponajprije: apsolutna i stvarna nadležnost suda (čl. 16. i 17. ZPP-a F BiH), nedostatak stranačke i parnične sposobnosti (čl. 291.

53 Pozitivne procesne pretpostavke su one bez čijeg postojanja meritorno raspravljanje i meritorno suđenje nije dopušteno.

54 Procesne pretpostavke su okolnosti od čijeg postojanja zavisi dopustivost pokretanja parničnog postupka, raspravljanja u parnici, donošenje meritorne odluke o osnovanosti tužbenog zahtjeva, odlučivanje o pravnim lijekovima te o incidentalnim zahtjevima koji bi se mogli iznijeti tijekom parničnog postupka. Od postojanja procesnih pretpostavki zavisila bi dopustivost meritornog raspravljanja, u krajnjoj liniji, meritornog suđenja. Usp. M. Dika, Pravo na tužbu, Zagreb, 1987. (dalje - DIKA, Pravo na tužbu), str. 310. - 311., TRIVA - DIKA, o. c., str. 28.

${ }_{55} \quad$ ZPP BD u čl. 307., za razliku od ZPP F BiH, ZPP RS i ZPP BiH, kao posebnu pretpostavku za donošenje presude zbog propuštanja propisuje dužnost tužitelja da uz tužbu dostavi dokaze koji se po svojoj prirodi mogu dostaviti.

56 Tako S. Triva, Građansko procesno pravo, Parnično procesno pravo, Zagreb, 1972., str. 512.; S. Triva, Građansko parnično procesno pravo, NN, Zagreb, 1978., str. 489. 
i 293. ZPP-a F BiH) ili urednog zastupanja tužitelja, postojanje druge parnice o istom zahtjevu među istim strankama (litispedencija, čl. $60 \mathrm{ZPP}-\mathrm{a} F \mathrm{BiH}$ ), postojanje pravomoćne presude (čl. 196. ZPP-a F BiH), sudska nagodba (čl. 93 ZPP-a F $\mathrm{BiH}$ ), okolnost zbog kojih bi sudac koji treba donijeti presudu zbog propuštanja morao biti isključen u konkretnoj parnici (čl. 357. i 360. ZPP-a F BiH). ${ }^{57}$

\subsubsection{Uredno dostavljena tužba i poziv za davanje odgovora na tužbu}

Presuda zbog propuštanja može se donijeti samo ako su, između ostalog, tuženiku tužba i poziv za davanje odgovora na tužbu uredno dostavljeni. Tuženiku je uredno dostavljen poziv za davanje odgovora na tužbu: ako je pozvan sukladno odredbama ZPP-a F BiH o dostavi, ako mu je uredno dostavljen i primjerak tužbe te ako je u pozivu upozoren na pravne posljedice nepodnošenja odgovora na tužbu (arg. čl. 70. st. 2. ZPP-a F BiH). Tuženiku tužba mora biti dostavljena prema pravilima o tzv. osobnoj dostavi. ${ }^{58}{ }^{59}$ Dokaz o urednom pozivu pruža dostavnica o uručenju tužbe tuženiku, koju potpisuje primatelj i dostavljač. ${ }^{60}$ Ako uz tužbu postoje prilozi, i oni moraju biti dostavljeni (arg. čl. 69. ZPP F BiH). Ako je podnesena tužba bez priloženih - predloženih dokaza, sud tužbu treba dostaviti tuženiku na odgovor, te ako je tužitelj u tužbi predložio donošenje presude zbog propuštanja, a tuženik ne odgovori na tužbu, sud treba provjeriti nepostojanje očite neosnovanosti zahtjeva samo na temelju činjeničnih navoda tužbe i predloženih dokaza (koji nisu dostavljeni uz tužbu) ${ }^{61} \mathrm{Iz}$ odredbe čl. 53. ZPP-a F BiH, a niti iz ijedne druge odredbe, ne proizlazi dužnost tužitelja da uz tužbu dostavi dokaze koje je predložio,

$57 \quad$ Vidjeti Čizmić - Komentar, o. c. str. 512.

58 Vidjeti čl. 347. ZPP-a F BiH. Istovjetna je odredba čl. 347. ZPP RS, čl. 101. ZPP BD.

Prema stajalištu sudske prakse nisu ispunjene pretpostavke za donošenje presude zbog ogluhe kad je na poziv suda dostavljen pisani odgovor na tužbu po osobi koja nije dokazala svojstvo zastupnika ili punomoćnika, a prije nego što sud poduzme radnje radi otklanjanja nedostataka u zastupanju tuženika. Presuda Županijskog suda u Bjelovaru, Gž. 138/2010-2 od 11.02.2010. Ukoliko je tuženik bez zakonitog razloga odbio primiti tužbu s pozivom za davanje odgovora na tužbu, dostavljač je dužan isto naznačiti na pismenu i vratiti ga sudu, a u stanu tuženika odnosno u poštanskom sandučiću ostaviti obavijest o pokušanoj dostavi s upozorenjem da će se dostava obaviti preko oglasne ploče suda, te se smatra da je dostava obavljena istekom roka od 8 dana od stavljanja pismena na oglasnu ploču suda. Presuda Županijskog suda u Varaždinu, Gž. 554/09-2 od 11. 5. 2009.: vizura. eu/praksa/presuda-zbog-ogluhe-članak 331- b/ Vidjeti čl. 351. ZPP F BiH, odnosno 351. ZPP RS, te čl. 290. ZPP BiH i čl. 108. ZPP BD.

Tako i Cimirotić, M., Materijalna pretpostavka za donošenje presude zbog propuštanja, Domaća i strana sudska praksa, 2016., (dalje - CIMIROTIĆ), str. 12., Usp. Triva - Dika o. c., str. 395. 
već ih je dužan samo predložiti - navesti u tužbi (može ih i dostaviti), ali ih je dužan podnijeti sudu tek na pripremnom ročištu. ${ }^{2}$ Dakle, iz navedene odredbe proizlazi da prilozi nisu obvezan sastojak tužbe i da ne utječu na njezinu potpunost, odnosno urednost. ${ }^{63}$ Smatramo da bi bolje rješenje bilo da je propisana obveza tužitelja da uz tužbu dostavi dokaze koji se po svojoj prirodi mogu dostaviti (isprave, zapisnik o osiguranju dokaza i sl.) kako bi sud mogao kvalitetno provjeriti materijalno pravnu pretpostavku za donošenje presude zbog propuštanja i donijeti pravilnu odluku.

\subsubsection{Prijedlog tužitelja za donošenje presude zbog propuštanja}

Da bi sud mogao donijeti presudu zbog propuštanja potrebno je između ostalog i da tužitelj u tužbi predloži donošenje presude zbog propuštanja (čl. 182. st. 1. ZPP F BiH). ${ }^{64}$ Ako tužitelj u tužbi ne zatraži donošenje presude zbog propuštanja, a tuženik u zakonskom roku ne dostavi odgovor na tužbu, tada sud nakon isteka roka za podnošenje odgovora na tužbu treba zakazati pripremno ročište (arg. čl. 75. st. 2. ZPP F BiH). ${ }^{65}$ Nasuprot ovakvom zakonskom rješenju mišljenja smo da prijedlog tužitelja, kao jedna od pretpostavki za donošenje presude zbog propuštanja, nije potreban i da se zakazivanjem pripremnog ročišta, ako se on ne podnese, ne doprinosi općoj učinkovitosti i ekonomičnosti postupka. Tužitelj nema pravnog interesa protiviti se njezinom donošenju, a donošenje presude utemeljene na izvođenju dokaza i kontradiktorno provedene rasprave ne pruža tužitelju kvalitetniji stupanj pravne zaštite od one koju mu pruža presuda zbog propuštanja.

62 U pozivu za pripremno ročište sud će obavijestiti stranke o posljedicama izostanka sa pripremnog ročišta, kao i o tome da su dužne najkasnije na pripremnom ročištu iznijeti sve činjenice na kojima temelje svoje zahtjeve i predložiti sve dokaze koje žele izvesti u tijeku postupka, te na pripremno ročište donijeti sve isprave i predmete koje žele upotrijebiti kao dokaz (arg. iz čl. 77. ZPP F BiH i ZPP RS).

63 Sud nije ovlašten pozvati tužitelja da tužbu ispravi, odnosno dopuni zbog razloga koji se odnose na osnovanost tužbenog zahtjeva. (OS u Splitu, Gž-2149/89 od 8. rujna 1989.PSP 43/10). U tom pravcu i odluke VTSRH, Pž-3562/01 od 09. 04. 2002. i Pž-5843/01 od 01. 04. 2003. Podatak kod Grbin, I., Zakon o parničnom postupku, sa sudskom praksom, bilješkama, napomenama, prilozima i abecednim kazalom pojmova, šesto, izmijenjeno i dopunjeno izdanje, Organizator, Zagreb, 2012., (dalje - GRBIN - ZPP), str. 132. - 134. Isto rješenje predviđa odredba čl. 182. st. 1. ZPP RS. Istovjetne su odredbe čl. 306. st. 1. ZPP BD, te čl. 149. st. 1. ZPP BiH 


\subsubsection{Propuštanje da se u roku podnese odgovor na tužbu}

Sljedeći uvjet koji mora biti ispunjen da bi sud donio presudu zbog propuštanja je da je tuženi propustio u zakonskom roku odgovoriti na tužbu i time se od tužbe braniti. ${ }^{66}$ Moguća je situacija da je tuženi odgovorio na tužbu, ali da je odgovor na tužbu nerazumljiv ili nepotpun. Tada će sud će radi otklanjanja tih nedostataka vratiti tuženiku odgovor na tužbu radi ispravke ili dopune, uz navode što treba ispraviti ili dopuniti i odrediti mu rok za ispravku ili dopunu podneska, koji ne može biti duži od osam dana (čl. 73. ZPP F BiH). Ukoliko odgovor na tužbu bude odbačen ili povučen u skladu s čl. 336. st. 3. ZPP F BiH, smatrat će se da tuženi nije dao odgovor na tužbu. Dakle, u tom slučaju važi fikcija da tuženi nije dostavio odgovor na tužbu. Tada će sud, smatrajući da je tuženi propustio odgovoriti na tužbu, donijeti presudu zbog propuštanja, ukoliko su ispunjeni i ostali zakonom predviđeni uvjeti.

\subsubsection{Očita neosnovanost tužbenog zahtjeva}

Prema odredbi čl. 182. st.1. ZPP F BiH kad tuženik, kome je uredno dostavljena tužba u kojoj je tužitelj predložio donošenje presude zbog propuštanja, ne dostavi pismeni odgovor na tužbu u zakonskom roku, sud će donijeti presudu kojom se prihvaća tužbeni zahtjev (presuda zbog propuštanja), osim ako je tužbeni zahtjev očito neosnovan. Dakle, u svim slučajevima kada su ispunjeni svi propisani uvjeti i kada je zahtjev utemeljen sud je ovlašten donijeti presudu zbog propuštanja, a u slučajevima neutemeljenosti zahtjeva donosi presudu kojom tužbeni zahtjev odbija. ${ }^{67}$ Stav 2 . istog člana propisao je dvije situacije u kojima se smatra da je tužbeni zahtjev očito neosnovan. Prva, ako je tužbeni zahtjev očito protivan činjenicama navedenim u tužbi, a druga ako su činjenice na kojima se temelji tužbeni zahtjev u očitoj protivnosti s dokazima koje je sam tužitelj predložio ili s činjenicama koje su opće poznate ${ }^{68}$ Postojanje očite protivnosti tužbenog

66 Prema stajalištu starije sudske prakse Sud nije mogao donijeti presudu zbog izostanka ako nije protekao rok koji je sud odredio za podnošenje odgovora na tužbu. (VPS Sl. 563/67, Zb. XII/2-275). Podnesak punomoćnika tužene strane kojim prije održavanja pripremnog ročišta obavještava sud da je imenovan zastupnikom i da mu se uputi poziv za raspravno ročište, ima značenje osporavanja tužbenog zahtjeva, pa se u takvom slučaju ne može donijeti presuda zbog izostanka. (VS BiH Gž. 183/69, Zb. XIV/2-170). Podatak kod Vuković, Š., Zakon o parničnom postupku sa sudskom praksom i objašnjenjima, 2. izmijenjeno i dopunjeno izdanje, Savremena administracija, Beograd, 1974. str. 127

67 Vidi Presudu Županijskog suda u Mostaru br. 580 Ps 901694 od 02. 04. 2008. 
zahtjeva s činjenicama navedenim u tužbi utvrđuje sud. Sud, dakle, meritorno odlučuje na temelju činjenica koje iznosi tužitelj. Te činjenice mogu biti takve da tužbeni zahtjev čine utemeljenim ili takve da ga čine očito neutemeljenim. ${ }^{69}$ Presuda zbog propuštanja ima osnovu u zakonskoj pretpostavci da tuženi priznaje činjenične navode iz tužbe, ali ne i tužbeni zahtjev. Priznate činjenice ne treba dokazivati, osim ako se radi o nedopuštenim raspolaganjima stranaka. No, ovako utvrđeno činjenično stanje sud mora podvesti pod odgovarajuće pravno pravilo. Sud može usvojiti tužbeni zahtjev samo ako iz činjenica navedenih u tužbi proizlazi da tužbeni zahtjev nije očito neosnovan. Tako u parnici za naknadu štete iz činjeničnih navoda mora proizlaziti da je tuženi odgovoran za štetu i da je visina štete primjerena. Ako ova pretpostavka nije ispunjena, sud neće odbiti da donese presudu, nego će u tom slučaju izreći presudu kojom se tužbeni zahtjev odbija. ${ }^{70}$

Druga situacija u kojoj se smatra da je zahtjev očito neosnovan je ona u kojoj činjenice na kojima se temelji tužbeni zahtjev ne smiju biti u očitoj protivnosti s dokazima koje je sâm tužitelj predložio ili s činjenicama koje su općepoznate. Sud ne može zahtijevati od tužitelja da podnese dokaze, odnosno da uz tužbu dostavi dokaze koje je predložio, jer ih je prema odredbi čl. 77. ZPP F BiH dužan podnijeti sudu najkasnije na pripremnom ročištu. Ali ponekad se događa da tužitelj uz tužbu priloži takve isprave koje svojim sadržajem opovrgavaju činjenične navode $u$ tužbi. ${ }^{71}$ Okolnost da tužitelj uz tužbu nije dostavio predložene dokaze kojima se dokazuju činjenični navodi iz tužbe ne predstavlja zapreku za donošenje presude zbog propuštanja. $U$ toj situaciji sud procjenjuje podobnost predloženog dokaznog sredstva za dokazivanje određene činjenice iz tužbe. To znači da sud zaključak o istinitosti činjenične tvrdnje izvodi tako što temeljem općeg životnog i pravničkog iskustva procjenjuje bi li predloženi dokaz mogao dokazati činjenice koje tužitelj njime hoće dokazati. Ako sud zaključi da bi taj

69 Vidi Čizmić - Komentar, o. c., str. 502.

70 Vidjeti Zakon o parničnom postupku s komentarom, str. 150. Presuda zbog izostanka ne može se donijeti u parnicama za naknadu štete, ako visina tražene naknade ne proizlazi iz činjenica navedenih u tužbi. Visina naknade ne proizlazi iz činjenica navedenih u tužbi, ako su u tužbi navedene samo povrede i označena visina tražene naknade, a nisu navedene činjenice iz kojih proizlazi osnovanost visine naknade. Vrhovni sud Srbije, Gž. 2378/76 od 10. septembra 1976. godine. Jedna od pretpostavki za donošenje presude zbog izostanka je i da osnovanost tužbenog zahtjeva proizlazi iz činjenica navedenih u tužbi. Navedena pretpostavka nije se ostvarila, ako tužitelj koji traži naknadu neimovinske štete ne pridonese nikakve dokaze da je takvu štetu pretrpio. Viši privredni sud Hrvatske, Gzz -143/75 od 15.1.1976. Podatak kod Janković, o. c., str. 394. - 395.

To bi bila situacija kada tužitelj traži isplatu kupoprodajne cijene u iznosu od deset hiljada dinara, a prilaže kupoprodajni ugovor u kome je navedeno da kupoprodajna cijena iznosi osam hiljada dinara (Ibid., str.150.) 
dokaz mogao biti izvor spoznaje činjenica na kojima se temelji zahtjev, tada treba provjeriti je li tužbeni zahtjev protivan tim činjenicama, pa ako nije, slijedilo bi da tužbeni zahtjev nije očito neosnovan. ${ }^{72}$

Sud također ne može donijeti presudu zbog propuštanja ako su činjenice na kojima se temelji tužbeni zahtjev u suprotnosti s općepoznatim (notornim) činjenicama. Ako sud utvrdi da su činjenice na kojima se temelji tužbeni zahtjev u suprotnosti s dokazima koje je sam tužitelj podnio ili s činjenicama koje su općepoznate, ne može donijeti presudu zbog propuštanja, a ako bi ona bila donesena, takva bi se presuda mogla pobijati zbog bitne povrede odredbi parničnog postupka (čl. 209. st. 2. toč. 6. ZPP FBiH). ${ }^{73}$ Zakon ne određuje opseg notornosti. Iako zakon u svojim odredbama izričito ne navodi, držimo da se unatoč tome što su se ispunili svi ostali uvjeti, presuda zbog propuštanja ne bi mogla donijeti ako postoje općepoznate okolnosti iz kojih proizlaze opravdani razlozi koji su tuženika spriječili da podnese odgovor na tužbu (npr. vremenske neprilike). ${ }^{74}$

\subsubsection{Zahtjevi s kojima stranke ne mogu raspolagati}

Specifična pretpostavka za donošenje presude zbog propuštanja jest da se parnica mora voditi o zahtjevima kojima stranke mogu slobodno raspolagati. Prema odredbi čl. 182. st. 4. ZPP F BiH ${ }^{75}$ presuda zbog propuštanja neće se donijeti o zahtjevu ili dijelu zahtjeva kojim stranke ne mogu raspolagati. Dakle, sud ne bi smio donijeti presudu zbog propuštanja i kada je udovoljeno uvjetima iz čl. 182. st.1. i 2. ZPP F BiH, ako bi našao da je riječ o zahtjevu kojima stranke ne mogu raspolagati (čl. 3. st. 2. ZPP F BiH) ${ }^{76}$ Nadalje, dispozicija predmetom spora u nekim je statusnim stvarima ex lege isključena kao npr. u bračnim i paternitetskim sporovima. Granice materijalno-pravne dispozitivnosti ujedno su i granice unutar kojih se presuda zbog propuštanja može kretati. ${ }^{77}$

$72 \quad$ Vidi Cimrotić, o.c., str.13.

73 Tako i Čizmić, J., „Presuda zbog ogluhe“, Informator, broj 5168, od 17. 9. 2003., str. 11.

$74 \quad$ Vidi Haubrich, o. c., str. 407.

75 Istovjetna je odredba čl. 182. st. 4. ZPP RS, 149. ST. 4. ZPP BiH. Odredba čl. 307. ZPP BD propisuje u posebnom članu posebne pretpostavke za donošenje presude zbog propuštanja, pa se presuda zbog propuštanja neće donijeti ako tužitelj uz tužbu nije dostavio dokaze koji se po svojoj prirodi mogu dostaviti i o zahtjevu ili dijelu zahtjeva kojim stranke ne mogu raspolagati.

76 Čl. 3. st.2. ZPP RS, čl. 3. st. 2. ZPP BD, čl. 8. st. 2. ZPP BiH.

77 Pogledaj kod Čizmić - Komentar, o. c. , str. 511. 
KEVO, M., Pravne posljedice propuštanja odgovora na tužbu Zbornik radova Pravnog fakulteta Sveučilišta u Mostaru, br. XXVII., 2019., str. 84. - 120.

\section{Pravni lijekovi/ pravna sredstva protiv presude zbog propuštanja}

\section{1. Žalba protiv presude zbog propuštanja}

Zakon o parničnom postupku iz 2003. godine $\mathrm{F} \mathrm{BiH} \mathrm{u} \mathrm{čl.} \mathrm{183.} \mathrm{propisivao} \mathrm{je}$ da protiv presude zbog propuštanja tuženik može podnijeti prijedlog za povrat $u$ prijašnje stanje, dok žalba nije bila dopuštena. Pravovremeno podneseni prijedlog za povrat u prijašnje stanje sprječavao je da presuda zbog propuštanja postane pravomoćna. Ako sud udovolji prijedlogu za povrat u prijašnje stanje, tuženik je dužan snositi sve troškove koji su nastali do donošenja presude zbog propuštanja. ${ }^{78}$ Ovakvo zakonsko rješenje prema kojem se presuda zbog propuštanja pobijala samo prijedlogom za povrat u prijašnje stanje, kao pravnim sredstvom, a ne žalbom, kao pravnim lijekom, bilo je protivno čl. II/A/2/C i C/1/4/2 Ustava Federacije BiH, odnosno čl. 16. st. 2. Ustava Republike Srpske, kao i odredbi čl. 203. st. 1. ZPP-a, kojom je propisano da stranke protiv presuda donesenih u prvom stupnju mogu podnijeti žalbu. Također, ovakvo je rješenje bilo u suprotnosti s odredbom čl. 13. Konvencije kojom se svakome jamči pravo na djelotvoran pravni lijek. Zbog toga je u pravnoj teoriji i praksi naišlo na niz kritika, koje su, pored navedenih razloga, bile upućene i k tomu da je ovakvo rješenje izrazito strogo, jer se propisanim pravnim sredstvom - prijedlogom za povrat ni izdaleka ne može postići kvaliteta pravne zaštite koju pruža žalba. Prije svega, da bi sud uopće ispitivao zakonitost donesene odluke, koja je mogla biti donesena povredom pravila postupka koje se odnose na uvjete za njezino donošenje (ako je donesena iako je tužbeni zahtjev očito neosnovan), tuženik mora dokazati da je iz opravdanih razloga, koje nije mogao predvidjeti niti izbjeći, propustio dati odgovor na tužbu. Uz problem utvrđivanja pojma opravdanih razloga koji nisu egzaktno navedeni, tuženikova mogućnost zaštite njegovih prava ovisila je o tumačenju ove odredbe od strane suda, i to onog koji je donio takvu odluku, jer se radilo o remonstrativnom pravnom lijeku.

Zbog prednje navedenih kritika Zakonodavac je odredbom čl. 30. Izmjena ZPP F BiH odnosno odredbe čl. 30 Izmjene ZPP RS brisao odredbu čl. 183., koja je izričito isključivala žalbu protiv presude zbog propuštanja i koja je prijedlog za povrat u prijašnje stanje predviđala kao jedino dopušteno pravno sredstvo protiv ove presude. Navedenim Izmjenama ZPP F BiH i ZPP RS kao osnovni redovni pravni lijek protiv presude zbog propuštanja uvedena je žalba, koja predstavlja ograničen pravni lijek jer je žalitelj ne može izjaviti iz svih zakonom predviđenih razloga. Odredbom čl. 33. Izmjena ZPP F BiH odnosno čl. 33. Izmjena ZPP RS u čl. 208. dodan je novi stav. 2. koji propisuje da se presuda zbog propuštanja ne

Istovjetne su bile odredbe čl. 183. ZPP RS, čl. 296. st. 1. ZPP BD. 
može pobijati zbog pogrešno ili nepotpuno utvrđenog činjeničnog stanja. ${ }^{79}$ To je posljedica činjenice da sud prilikom donošenja ove presude nije utvrđivao činjenično stanje, koje nije bilo osporeno.

Iz navedenih se odredbi a contrario zaključuje da se presuda zbog propuštanja može pobijati zbog bitnih odredbi parničnog postupka i zbog pogrešne primjene materijalnog prava.

Odredbom čl. 34. Izmjena ZPP F BiH odnosno čl. 34. Izmjena ZPP RS izmijenjen je čl. 209. ZPP, tako da je navedenim čl. u st. 2. toč 6. ZPP čl. 209. propisano da bitna povreda odredbi parničnog postupka postoji ako je sud protivno odredbama ZPP donio presudu zbog propuštanja ${ }^{80}$ Bitna povreda odredbi parničnog postupka postoji i kad je sud protivno odredbama ZPP zasnovao svoju odluku na nedozvoljenim raspolaganjima stranaka ili je nezakonitim postupanjem, a osobito propuštanjem dostavljanja, onemogućio stranku da raspravlja pred sudom. ${ }^{81} 8283$

Presuda zbog propuštanja može se pobijati i zbog pogrešne primjene materijalnog prava. Pogrešna primjena materijalnog prava postoji kad sud nije primijenio odredbu materijalnog prava koju je trebao primijeniti ili kada takvu odredbu nije pravilno primijenio. ${ }^{84}$ Prilikom donošenja presude zbog propuštanja sud

79 Prema stajalištu sudske prakse okolnost da se žalba protiv presude zbog ogluhe poziva na žalbeni razlog pogrešnog i nepotpuno utvrđenog činjeničnog stanja zbog kojeg se žalba ne može izjaviti ne čini je nedopuštenom. Presuda Županijskog suda u Zagrebu, Gž. 6906/06 od 20. 03. 2007., vizura.eu>praksa>razlozi-zbog-kojih-se-prsuda-može-pobijati-članak 353.

Isto je propisano odredbom čl. 206. st. 2. toč 6. ZPP RS, čl. 329. st. 2. toč f. ZPP BD, te odredbom čl. 176. st. 2. toč. 4. ZPP BiH.

Vidi čl. 227. st. 1. toč.1 ZPP F BiH, čl. 227. st. toč. 1. ZPP RS, čl. 347. st. toč. b. ZPP BD, $\mathrm{BiH}$.

Rješenjem Županijskog suda u Širokom Brijegu uvažena je žalba tuženika, prvostupanjska presuda ukinuta i predmet vraćen prvostupanjskom sudu na ponovno suđenje. U obrazloženju rješenja se navodi da iz stanja spisa proizlazi da tužba nije dostavljena sukladno odredbama 347. st. 1 i 2. ZPP F BiH nego je pismeno predato supruzi tuženika odmah pri prvom pokušaju dostave. Dakle, propuštanjem dostave tuženiku nije data mogućnost da raspravlja pred sudom, a to je bilo od utjecaja na donošenje zakonite i pravilne presude. Vidi Rješenje Županijskog suda Široki Brijeg br.: 640 Mal 04251516 Gž od 28. 05. 2018. godine.

„Iz stanja spisa proizlazi da je tuženoj uredno dostavljena tužba s prilozima uz dopis suda i poukama u pogledu podnošenja odgovora na tužbu kako je to i propisano odredbama čl. 69. i 70. ZPP -a F BiH te da tužena u ostavljenom roku nije podnijela odgovor na tužbu čime su se ispunili uvjeti iz čl. 182. st. 1. ZPP - a F BiH tj. Za donošenje." Vidi Presudu Županijskog suda u Širokom Brijegu broj 640 Mal 04176117 Gž od 27. 04. 2018. godine. Vidi čl. 211. ZPP F BIH, čl. 211 ZPP RS, čl. 331. ZPP BD, čl. 178. ZPP BiH. 
utvrđuje proizlazi li očita neosnovanost tužbenog zahtjeva iz činjenica navedenih u tužbi. Dakle, procesni materijal i činjeničnu podlogu odluke o tužbenom zahtjevu čine samo one činjenice koje je tužitelj naveo, a tuženi ih nije osporio. $\mathrm{Na}$ takvoj podlozi sud primjenjuje materijalno pravo i odlučuje o tome je li tužiteljev zahtjev očito neosnovan i pripada li tužitelju pripada pravna posljedica koju je predložio. U ovakvoj primjeni sud može pogriješiti odnosno ne primijeniti normu koju je trebao primijeniti ili može pogrešno protumačiti i primijeniti neku drugu normu.

\subsection{Prijedlog za povrat u prijašnje stanje}

Prema odredbi čl. 328. ZPP F BiH, ako stranka propusti ročište ili rok za poduzimanje koje radnje u postupku i zbog toga izgubi pravo na poduzimanje te radnje, sud će toj stranci na njezin prijedlog dopustiti da naknadno obavi tu radnju (povrat u prijašnje stanje), ako ocijeni da je do propuštanja došlo uslijed opravdanih razloga koji se nisu mogli predvidjeti niti izbjeći. Kad se dopusti povrat $u$ prijašnje stanje, parnica se vraća u ono stanje $u$ kojem se nalazila prije propuštanja i ukidaju se sve odluke koje je sud zbog propuštanja donio. ${ }^{85}$ Tuženi može iz opravdanih razloga propustiti da odgovori na tužbu u zakonskom roku, što će uzrokovati donošenje presude zbog propuštanja, ako je to tužitelj predložio uz ispunjenje i svih drugih uvjeta, pa tada može izjaviti prijedlog za povrat u prijašnje stanje. Povrat u prijašnje stanje kao procesni institut služi otklanjanju štetnih posljedica propuštanja koje je učinjeno iz opravdanih razloga. On se može koristiti samo ako se propuštena radnja ne može naknadno poduzeti, s ciljem da se stranci omogući poduzimanje propuštanje radnje. ${ }^{86}$ Kod presude zbog propuštanja, tuženi zahtjeva povrat u prijašnje stanje jer je propustio $u$ zakonskom roku odgovoriti na tužbu, što je prouzrokovalo donošenje presude zbog propuštanja ukoliko su bili ispunjeni i ostali zakonom predviđeni uvjeti. Prijedlogom za povrat tuženi u stvari traži da se parnica vrati u stanje u kojem se nalazila prije propuštanja i da se ukine presuda zbog propuštanja. Da bi sud udovoljio ovakvom zahtjevu tuženika, trebaju biti kumulativno ispunjeni svi uvjeti

\footnotetext{
$85 \quad$ Istovjetna je odredba čl. $328 \mathrm{ZPP}$ RS, čl. 79. ZPP BD, 268. ZPP BiH.

86 Povrat u prijašnje stanje može se dozvoliti samo zbog propuštanja procesnih, a ne materijalno-pravnih rokova. Vrhovni sud Srbije, Y.3399/70. Povrat u prijašnje stanje može se dozvoliti samo ako je stranka propuštanjem ročišta ili roka za poduzimanje neke radnje u postupku izgubila pravo na poduzimanje te radnje. Okružni sud u Beogradu, Gž. 8943/73. Povrat u prijašnje stanje u parničnom postupku dozvoljava se samo na prijedlog zainteresirane stranke, a ne po službenoj dužnosti. Viši privredni sud Srbije, Pž-738/82; R. Ćosić, T. Krsmanović, Aktualna sudska praksa iz građanskog-procesnog prava, prvo izdanje, Beograd, 2003., (dalje - Ćosić - Krsmanović), str. 51.
} 
koje zakon predviđa. Prvi uvjet je ispunjen ako je tuženi u zakonskom roku od 30 dana od dana dostavljanja tužbe s poukom o posljedicama propuštanja propustio odgovoriti na tužbu. Dakle, ovu parničnu radnju tuženi ne bi mogao poduzeti u kasnijem tijeku postupka, što znači da je nastupila prekluzija, čime je i drugi uvjet ispunjen. Ako se propuštena procesna radnja može poduzeti naknadno, stranka tada nema pravni interes tražiti povrat jer i bez povrata može poduzeti tu istu radnju u sljedećim stadijima parnice. ${ }^{87}$ Tuženi također mora opravdati razlog propuštanja i dokazati da je opravdan razlog koji je uzrokovao propuštanje. ${ }^{88}$ Sljedeći je uvjet da zakonom nije isključena mogućnost traženja povrata u prijašnje stanje, te da se povrat u prijašnje stanje zahtjeva u zakonom propisanom roku. Zakonom su propisani rokovi u kojima tuženik može podnijeti prijedlog za povrat u prijašnje stanje, koji su u odnosu na ZPP 58, ZPP 78 i ZPP F BiH 98 znatno kraći. Predviđeni su dalje subjektivni i objektivni rok za izjavljivanje prijedloga za povrat u prijašnje stanje. Što se subjektivnog roka tiče, prijedlog se mora podnijeti u roku od osam dana, računajući od dana kada je prestao razlog koji je uzrokovao propuštanje, a ako je stranka tek kasnije saznala za propuštanje - od dana kada je za to saznala. ${ }^{89}$ Prema stajalištu starije sudske prakse, „rok za podnošenje prijedloga za povrat u prijašnje stanje računao se od dana primitka odluke koju je sud radi propuštanja donio, a ne od dana propuštanja. ${ }^{\text {"90 }}$ Ovakva praksa sudova utjecala je bitno na odugovlačenje postupka i slabljenje procesne discipline, što je vjerojatno utjecalo na zakonodavca da skrati i subjektivne i objektivne rokove. Objektivni rok za izjavljivanje prijedloga za povrat u prijašnje stanje iznosi 60 dana i nakon proteka tog roka od dana propuštanja, ne može se tražiti povrat u prijašnje stanje. ${ }^{91}$ On se uvijek računa od dana propuštanja. Prijedlog za povrat

Tako Triva, S., Građansko procesno pravo I, NN, Zagreb, 1965. str. 308.

U literaturi procesnog prava opravdanim razlogom se smatra postojanje nepredviđenog ili neotklonjivog događaja koji je spriječio poduzimanje određene radnje. Tako, Poznić, B., Rakić, Vodinelić, V., Građansko procesno pravo, Suvremena administracija, Beograd, 1999. str. 171.

Vidi čl. 329. st. 2. ZPP F BiH odnosno čl. 329. st. 2. ZPP RS, te čl. 80. st. 2. ZPP BD i 269. st. 2. ZPP BiH. Prema odredbama ZPP 58, ZPP 78 i ZPP F BiH 98, subjektivni rok je iznosio 15 dana.

Vidi Presuda Ops. u Titogradu, P-1736/76 od 5. srpnja 1977. Podatak kod Čizmić - Komentar, o. c., str. 937. Rok od 15 dana za podnošenje prijedloga za povrat u prijašnje stanje, zbog spriječenosti tuženog da dođe na pripremno ročište, odnosno na prvo ročište na glavnu raspravu kada pripremno ročište nije određeno - ako je zbog toga donijeta presuda zbog propuštanja - teče od dana kada mu je ova presuda uručena, jer je on tada saznao za propuštanje, a ne od dana kada je prestao razlog koji je prouzrokovao propuštanje. Vrhovni sud Srbije, Pž. 853/70, podatak kod Ćosić - Krsmanović, o. c., str. 51.

Vidi čl. 329. st. 3. ZPP F BiH odnosno čl. 329. st. 3. ZPP RS, te čl. 80. st. 3. ZPP BD i 269. st. 3. ZPP BiH. Prema odredbama ZPP 58, ZPP 78 i ZPP F BiH 98, objektivni rok je iznosio 3 mjeseca. 
u prijašnje stanje podnosi se sudu kod koga je trebalo obaviti propuštenu radnju i taj sud odlučuje o prijedlogu za povrat u prijašnje stanje. Prijedlog za povrat u prijašnje stanje može se odbaciti, odbiti ili usvojiti. Rješenje kojim se prijedlog za povrat u prijašnje stanje odbacuje sud će donijeti, ukoliko je prijedlog neblagovremen i nedopušten. O prijedlogu se, u pravilu, odlučuje na ročištu, osim ako su činjenice na kojima se prijedlog temelji općepoznate. Sud će donijeti rješenje kojim se prijedlog za povrat u prijašnje stanje smatra povučenim ako stranka koja je podnijela prijedlog ne dođe na ročište zakazano povodom prijedloga, a uredno je obaviještena. ${ }^{92}$ Ako sud utvrdi da je prijedlog neosnovan, on će ga i odbiti. To će biti situacija u kojoj tuženi nije dokazao opravdanost svog prijedloga, odnosno opravdanost razloga za propuštanje da odgovori na tužbu. ${ }^{93} 9495$

92 Vidi čl. 332. st. 3. ZPP F BiH, odnosno čl. 332. st. 3. ZPP RS, čl. 83. st. 3. ZPP BD, čl. 272. st. 3. ZPP BiH.

93 Iz sudske prakse: „Iz stanja spisa proizlazi, da tužena nije uz prijedlog za povrat u prijašnje stanje, a niti na ročištu zakazanom povodom tog prijedloga, predložila dokaze kojima bi se potvrdile njezine tvrdnje, tj. da tužbu s prilozima nije primila i da zbog toga nije bilo mjesta donošenju presude zbog propuštanja. Imajući u vidu naprijed istaknuto, pravilno je postupio prvostupanjski sud, za razliku od neutemeljnih navoda žalbe, kada je prijedlog za povrat u prijašnje stanje odbio kao neosnovan. Prednje stoga, što dostavnica potpisana od strane adresata (tužene) i dostavljača, s naznakom datuma prijema pismena, kao što je ovdje slučaj, predstavlja javnu ispravu koja služi kao dokaz o izvršenoj dostavi (dostava tužbe). Za činjenice navedene u dostavnici važi presumpcija istinitosti, dok se ne dokaže suprotno. Sama izjava tužene da tužbu nije primila, ne može biti dovoljan dokaz da se ta presumpcija obori. Vidi Rješenje Županijskog suda u Širokom Brijegu broj $640 \mathrm{Mal}$ 01580712 Gž od 29. 10. 2012. godine

„U obadvije dostavnice, dostavljač pošte, je kao osobu tuženika koja je izvršila prijem, označio - osobu sa protokola primetlja i kvalificirao kao osobno dostavljanje, što potvrđuje da je tuženi tužbu na odgovor zaprimio uredno. Cijeneći naprijed utvrđene činjenice i dovodeći ih u vezu sa čl. 328. Zakona o parničnom postupku, sud cijeni da tuženi nije propustio rok za dostavu pismenog odgovora na tužbu iz opravdanih razloga." Vidi Rješenje Općinskog suda u Mostaru broj 580 Mals 14745014 Mals 2 od 21. 05. 2015. godine.

Nesporno je da tuženik nije dao odgovor na tužbu koju je uredno zaprimio što sam potvrđuje, te da je upravo temeljem navedenog donijeta presuda zbog propuštanja, pa nije bilo mjesta da se dopusti povrat u prijašnje stanje u smislu čl. 328. st. 1. ZPP - a F BiH, a temeljem kojeg je prvostupanjski sud i donio svoje rješenje. Vidi Rješenje Županijskog suda u Širokom Brijegu broj 0640 Mal 00508610 Gž od 13. 12. 2010. godine, Rješenje Županijskog suda u Širokom Brijegu broj 0640 Mal 01416412 Gž od 10. 04. 2013. godine, Rješenje Županijskog suda u Širokom Brijegu broj 0640 Mal 01226813 Gž od 18. 04. 2013. godine, Rješenje Županijskog suda u Širokom Brijegu broj 0640 Mal 01986913 Gži od 21. 10. 2013. godine, Rješenje Županijskog suda u Širokom Brijegu broj $0640 \mathrm{Mal}$ 02200313 Gž od 05. 02. 2014. godine, Rješenje Županijskog suda u Širokom Brijegu broj 0640 Mal 02777014 Gž od 04. 11. 2014. godine i Rješenje Županijskog suda u Širokom Brijegu broj 0640 Mal 02429014 Gž 2 od 03. 12. 2014. godine. 
Rješenje kojim se odbija prijedlog stranke za povrat u prijašnje stanje mora sadržavati obrazloženje. Sud donosi rješenje kojim se prijedlog za povrat u prijašnje stanje usvaja ako utvrdi da je prijedlog osnovan. Istim rješenjem ukida odluke koje su donesene kao posljedica propuštanja, u ovom slučaju presuda zbog propuštanja, i sve ostale posljedice propuštanja. Sud vraća parnicu u stanje u kojem se nalazila prije propuštanja i tuženom omogućava da odgovori na tužbu i da se od tužbe brani, u situaciji kada tuženom tužba nije bila dostavljena u skladu s odredbama o dostavi tužbe, pa je za nju saznao tek u trenutku prijema presude zbog propuštanja, odnosno uvažava njegov odgovor koji je trebao biti podnesen istovremeno s prijedlogom za povrat, u situaciji kada iz opravdanih razloga, primjerice bolesti, nije odgovorio na tužbu u zakonskom roku, a za nju je znao. Protiv rješenja kojim se usvaja prijedlog za povrat u prijašnje stanje nije dozvoljena žalba, osim ako je usvojen nepravovremen i nedozvoljen prijedlog. Protiv rješenja kojim se odbija prijedlog za povrat u prijašnje stanje žalba je dozvoljena. ${ }^{96}$

\section{Komparativni prikaz presude zbog propuštanja}

\subsection{Presuda zbog propuštanja u hrvatskom parničnom postupku}

Presuda zbog propuštanja u parničnom postupku Republike Hrvatske ${ }^{97}$ uvedena je Novelom iz 2003. godine unošenjem u Zakon o parničnom postupku RH novog čl. 331. (b) kojim se uvodi institut presude zbog ogluhe. ${ }^{98}$ Ako tuženik ne podnese odgovor na tužbu u određenom roku, donijet će se presuda kojom se prihvaća tužbeni zahtjev (presuda zbog ogluhe), ako bude udovoljeno ovim uvjetima: 1) ako su tuženiku tužba i poziv za davanje odgovora na tužbu uredno dostavljeni, 2) ako osnovanost tužbenog zahtjeva proizlazi iz činjenica navedenih u tužbi, 3) ako činjenice na kojima se temelji tužbeni zahtjev nisu u protivnosti s dokazima koje je sam tužitelj podnio ili s činjenicama koje su općepoznate, 4)

\footnotetext{
96 Vidi čl. 333. ZPP F BiH, odnosno čl. 333. ZPP RS, te čl. 84. ZPP BD i čl. 273. ZPP BiH.

97 Ova presuda u Hrvatskom zakonodavstvu nosi naziv „Presuda zbog ogluhe“.

98 Republika Hrvatska preuzela je Zakonom o preuzimanju Zakona o parničnom postupku od 26. lipnja 1991. godine (Narodne novine br. 53/91) savezni ZPP 76 kao Zakon Republike Hrvatske, s tim da se taj Zakon primjenjuje u Republici Hrvatskoj ako su njegove odredbe u suglasnosti s Ustavom i zakonima Republike Hrvatske. Preuzeti Zakon o parničnom postupku je više puta noveliran (Narodne novine br. 91/1992., 112/1999.) ali su tim novelama ostvarena tek neka dodatna, najviše terminološka usklađenja. U cilju pojednostavljenja i povećanja efikasnosti procesne procedure tijekom 2002. godine izrađen je Prijedlog zakona o izmjenama i dopunama Zakona o parničnom postupku (dalje - Novela) kojeg je Hrvatski sabor donio na sjednici održanoj 14. srpnja 2003. godine (Narodne novine, br. 117/03.),, a koji je stupio na snagu 1. prosinca 2003. godine.
} 
ako ne postoje općepoznate okolnosti iz kojih proizlazi da su tuženika spriječili opravdani razlozi da podnese odgovor na tužbu (čl. 331. (b). st. 1. ZPP RH).

Analizom pretpostavki za njezino donošenje zaključuje se da se može se donijeti po službenoj dužnosti, što jasno proizlazi iz odredbe čl. 331. st. 1. ZPP RH: "Donijet će se presuda kojom se prihvaća tužbeni zahtjev (presuda zbog ogluhe)", kao i na prijedlog tužitelja. Temeljni preduvjet za njezino donošenje je uredno dostavljena tužba tuženiku. Uz ovaj se uvjet veže i dužnost suda da tuženika u pozivu upozori na pravne posljedice nedavanja odgovora na tužbu. Kod pitanja uredne dostave, moguće je odgađanje donošenja presude zbog ogluhe ako nema dokaza da su tuženiku uredno dostavljeni tužba i poziv za davanje odgovora na tužbu, a nesumnjivo je da su mu upućeni. U tom će slučaju sud odrediti rok, koji ne može biti dulji od trideset dana za dostavu u zemlji odnosno dulji od šest mjeseci za dostavu u inozemstvu, kako bi izvidio jesu li tužba i poziv za davanje odgovora na tužbu tuženiku uredno dostavljeni. Ako bi se u tom roku utvrdilo da su ta pismena bila tuženiku uredno dostavljena, sud bi trebao donijeti presudu zbog ogluhe. ${ }^{99}$

Sljedeći je uvjet da je tuženik propustio u određenom roku podnijeti odgovor na tužbu. Kao što je dostava tužbe i pozivanje tuženika da podnese odgovor na tužbu postala obvezna parnična radnja suda, tako je i podnošenje odgovora na tužbu postala dužnost tuženika. On je dužan odgovoriti na tužbu u roku koji odredi sud, ali taj rok ne može biti kraći od trideset niti duži od četrdeset pet dana (čl. 285. st. 2. ZPP RH). U odgovoru na tužbu tuženik se može očitovati o zahtjevima i navodima tužbe, može priznati ili osporiti tužbeni zahtjev, također može i osporiti tužbeni zahtjev, ali i priznati činjenice na kojima se tužbeni zahtjev zasniva. Dakle, prema sadržaju odgovora na tužbu određeno je daljnje postupanje suda. Kada tuženi prizna odlučne činjenice, a ospori tužbeni zahtjev, sudac pojedinac, odnosno predsjednik vijeća može donijeti presudu bez održavanja rasprave, ako su ispunjeni i ostali uvjeti predviđeni zakonom (čl. 332. (a) ZPP-a RH). Ostali uvjeti koji moraju biti ispunjeni su: tuženik treba pravodobno podnijeti pisani odgovor na tužbu, postupak u kojem je tuženik priznao činjenice mora biti postupak u kojem su stranke u načelu ovlaštene poduzeti tu dispoziciju, tuženik treba u odgovoru na tužbu priznati odlučne činjenice navedene u tužbi, ali ne smije iznijeti tvrdnje o postojanju drugih činjenica koje svojim postojanjem dovode u pitanje osnovanost tužbenog zahtjeva, priznate činjenice ne smije biti u protivnosti s dokazima koje su same stranke priložile uz svoje podneske ili općepoznatim činjenicama, ne smije biti razloga koji bi izazvali sumnju da tuženik priznanjem ide za tim da raspolaže zahtjevima kojima ne može raspolagati. ${ }^{100}$

99 Član. 331.b st. 5. ZPP RH.

$100 \quad$ Vidi Triva - Dika, o. c., str. 617. - 618. 
Sljedeći su uvjeti za donošenje presude zbog ogluhe da osnovanost tužbenog zahtjeva proizlazi iz činjenica navedenih u tužbi. Dakle, kod materijalne pretpostavke za donošenje presude zbog ogluhe $\mathrm{u}$ ZPP-u RH sud treba utvrditi da, bez sumnje, osnovanost zahtjeva proizlazi iz činjenica tužbe. Uvjet za ovu presudu je i da činjenice na kojima se temelji tužbeni zahtjev nisu u protivnosti s dokazima koje je sam tužitelj podnio ili s činjenicama koje su općepoznate. Sam tužitelj navodi činjenice na kojima temelji tužbeni zahtjev, dokaze kojima se utvrđuju te činjenice. Ako iz činjenica navedenih u tužbi ne proizlazi osnovanost tužbenoga zahtjeva, sud će odrediti pripremno ročište i ako na tom ročištu tužitelj ne preinači tužbu, donijet će presudu kojom se tužbeni zahtjev odbija. ${ }^{101}$ Protiv rješenja suda kojim odbija prijedlog tužitelja da se donese presuda zbog ogluhe žalba nije dopuštena. ${ }^{102}$

Uvjet za donošenje presude zbog ogluhe je da ne postoje općepoznate okolnosti iz kojih proizlazi da su tuženika spriječili opravdani razlozi da podnese odgovor na tužbu. Ako sud nije siguran jesu li ispunjene sve pretpostavke za donošenje presude zbog ogluhe, trebao bi zastati s postupkom i odgoditi donošenje presude zbog ogluhe. Donošenje presude zbog ogluhe odgodit će se ako je potrebno da se o okolnostima iz stavka 2. novoga članka 331 (b) ZPP-a prije toga pribave obavijesti ${ }^{103}$, odnosno ako sud nađe da je potrebno izvidjeti raspolažu li stranke zahtjevima kojima ne mogu raspolagati. ${ }^{104}$

Presuda zbog ogluhe može se pobijati žalbom ${ }^{105}$, koja i u ZPP- RH predstavlja ograničen pravni lijek jer je žalitelj ne može izjaviti iz svih zakonom predviđenih razloga. Ona se može pobijati zbog bitne povrede odredbi parničnog postupka i zbog pogrešne primjene materijalnog prava, ali ne može se pobijati zbog pogrešno ili nepotpuno utvrđenog činjeničnog stanja.

Prema rješenjima ponuđenim u odredbama ZPP RH, za razliku od pravila koja predviđaju procesni zakoni u $\mathrm{BiH}$, sud ovu presudu donosi po službenoj dužnosti, ali i tužitelj može podnijeti prijedlog za njezino donošenje. Nadalje u ZPP RH kod materijalne pretpostavke za donošenje presude zbog propuštanja zakonodavac je propisao da osnovanost zahtjeva proizlazi iz činjenica navedenih u tužbi, te da je kao uvjet za njezino donošenje propisano i da ne postoje općepoznate okolnosti iz kojih proizlazi da su tuženika spriječili opravdani razlozi da odgovori na tužbu, što su bolja rješenja. Vezano uz rok za dostavu odgovora na tužbu

\footnotetext{
$101 \quad$ Član 331. (b) st. 4. ZPP RH.

102 Član 331. (b) st. 6. ZPP RH.

103 Član 331. (b) st 3. ZPP RH.

104 Član 3. st. 3. ZPP RH.

105 Član 353. st. 2. ZPP RH.
} 
zaključuje se da je zakonodavac u ZPP-u RH predvidio duži rok. On nije precizno određen, već ga određuje sud u svakom konkretnom slučaju, a može iznositi od trideset do četrdeset pet dana, za razliku od pravila predviđenih procesnim zakonima u $\mathrm{BiH}$, gdje rok iznosi trideset dana, što je bolje rješenje jer je precizno određen (jednak za sve), a uz to tuženiku je ostavljeno sasvim dovoljno vremena da se tuženi očituje o tužbenom zahtjevu.

\subsection{Presuda zbog propuštanja u srpskom parničnom postupku}

Institut presude zbog propuštanja u srpskom parničnom postupku propisan je odredbom čl. 350. Zakona o parničnom postupku Republike Srbije. ${ }^{106}$ Ako tuženi ne podnese odgovor na tužbu u određenom roku, sud donosi presudu kojom usvaja tužbeni zahtjev (presuda zbog propuštanja), ako su ispunjeni sljedeći uvjeti: tuženom je uredno dostavljena tužba s poukom o posljedicama propuštanja; činjenice na kojima se zasniva tužbeni zahtjev nisu u suprotnosti s dokazima koje je sam tužitelj podnio ili s činjenicama koje su općepoznate; osnovanost tužbenog zahtjeva proizlazi iz činjenica navedenih u tužbi; ne postoje općepoznate okolnosti iz kojih proizlazi da su tuženog spriječili opravdani razlozi da odgovori na tužbu. Ovi uvjeti moraju biti kumulativno ispunjeni da bi sud donio presudu kojom usvaja tužbeni zahtjev (presuda zbog propuštanja). Presuda zbog propuštanja na prijedlog tužitelja neće se donijeti u svim situacijama. Tako sud ovu presudu neće donijeti ni ako su ispunjeni ranije pobrojani uvjeti, ako se radi o zahtjevima kojim stranke ne mogu raspolagati. ${ }^{107}$ To su zahtjevi koji su u suprotnosti s prinudnim propisima, javnim poretkom i pravilima morala. Ako iz činjenica navedenih u tužbi ne proizlazi osnovanost tužbenog zahtjeva, sud će zakazati pripremno ročište, a ako tužba na pripremnom ročištu nije preinačena, sud će donijeti presudu kojom se tužbeni zahtjev odbija. ${ }^{108}$ Sud će odložiti donošenje presude zbog propuštanja ako je potrebno prethodno pribaviti obavještenja

106 Zakon o parničnom postupku, usvojen u Narodnoj skupštini Republike Srbije 26. listopada 2011. i objavljen u Službenom glasniku RS, broj 72/11., predstavlja drugi po redu zakon kojim je u državi Srbiji uređen parnični postupak. Ovaj zakon, koji je donesen po hitnom postupku radi ispunjenja međunarodnih obveza u cilju pridruživanja Europskoj uniji, prema odredbi čl. 588 ZPP RS, stupio je na snagu 1. veljače 2012., kada je prestao da važi Zakon o parničnom postupku iz 2004. (Službeni glasnik RS, br. 125/04 i 111/09). Vidi: Stanković, G., "Zakon o parničnom postupku prema stanju zakonodavstva“ od 31. maja 2014 godine, Objašnjenja, tumačenja i stvarni registar, 11 izdanje, Službeni glasnik, 2018., (dalje - STANKOVIĆ - ZPP) Beograd, str. 7., te 49/13., odluka US 74/13, odluka US 55/14., 87/18 (dalje - ZPP RS).

107 Vidi čl. 350. st. 2. ZPP RS.

108 Član 350. st. 3. ZPP RS. 
na temelju kojih utvrđuje radi li se o nedopuštenim raspolaganjima stranaka. Donošenje presude zbog propuštanja može se odložiti i ako nema dokaza da je tuženom uredno dostavljena tužba, a nesumnjivo je da mu je tužba poslana. U tom slučaju sud određuje rok koji ne može biti duži od 30 dana, kako bi se provjerilo je li tuženom uredno dostavljena tužba. Ako se u određenom roku utvrdi da je tuženom bila uredno dostavljena tužba, sud će donijeti presudu zbog propuštanja. ${ }^{109} \mathrm{U}$ ovim slučajevima, nakon što pribavi obavještenja, sud može donijeti presudu zbog propuštanja bez izjašnjavanja stranaka. ${ }^{110}$ Moguća je situacija da je tuženi podnio odgovor na tužbu, ali da odgovor ima nedostatke (formalne ili sadržajne prirode) zbog kojih se po njemu ne može postupiti. Tada će sud smatrajući da tuženi nije dao odgovor na tužbu, uz ispunjenje i ostalih zakonom predviđenih uvjeta, donijeti presudu zbog propuštanja.

ZPP RS na identičan način kao i ZPP RH uređuje institut presude zbog propuštanja. I u ZPP-u RS sud ovu presudu donosi po službenoj dužnosti, ali i tužitelj može podnijeti prijedlog za njezino donošenje. Također, kao u ZPP RH kod materijalne pretpostavke za donošenje presude zbog propuštanja u ZPP-u RS zakonodavac je propisao da osnovanost zahtjeva proizlazi iz činjenica navedenih u tužbi, te da je kao uvjet za njezino donošenje propisano i da ne postoje općepoznate okolnosti iz kojih proizlazi da su tuženika spriječili opravdani razlozi da odgovori na tužbu. Nadalje, zakonodavac je predvidio stroža pravila vezano za postupanje s nepotpunim odgovorom na tužbu u odnosu na nepotpunu/neurednu tužbu, čime je narušio procesnu ravnotežu između tužitelja i tuženika. U slučaju neuredne/nepotpune tužbe sud će je vratiti na ispravku ili dopunu, dok u situaciji da odgovor ima nedostatke zbog kojih se po njemu ne može postupiti, sud isti odbacuje, bez prethodnog pozivanja tuženika da ga dopuni.

\subsection{Presuda zbog propuštanja u crnogorskom parničnom postupku}

Institut presude zbog propuštanja u parničnom postupku Republike Crne Gore propisan je odredbom čl. 339. st. 1. Zakona o parničnom postupku Republike Crne Gore. ${ }^{111}$

Ako tuženi u roku od 30 ne odgovori na tužbu, sud donosi presudu kojom usvaja tužbeni zahtjev (presuda zbog propuštanja), ako su ispunjeni sljedeći uvjeti: ako

109 Vidi čl. 350. st. 4. i 5. ZPP RS.

$110 \quad$ Vidi čl. 350. st. 6. ZPP RS.

111 Zakon o parničnom postupku Republike Crne Gore Službeni list Republike Crne Gore, br. 22/04., 28/2005. odluka US i 76/2006 i Službeni list Republike Crne Gore, br.47/2015. - dr. zakon, 48/2015., 51/2017., 75/2017. - odluka US 62/2018. - odluka US (dalje - ZPP Crne Gore). 
je tuženom uredno dostavljena tužba na odgovor, ako se ne radi o zahtjevu kojim stranke ne mogu raspolagati (član 4. stav 3.), ako osnovanost tužbenog zahtjeva proizlazi iz činjenica koje su navedene u tužbi, ako činjenice na kojima se zasniva tužbeni zahtjev nisu u suprotnosti s dokazima koje je dostavio sam tužitelj ili s činjenicama koje su općepoznate. Donošenje presude zbog propuštanja odložit će se ako je potrebno da se o okolnostima iz stava 1 . ovog člana prethodno pribave obavještenja.

ZPP Crne Gore također određuje da za donošenje ove presude nije potreban prijedlog tužitelja. Također, kao u ZPP-u RH i ZPP-u RS kod materijalne pretpostavke za donošenje presude zbog propuštanja u ZPP-u Crne Gore zakonodavac je propisao da osnovanost zahtjeva proizlazi iz činjenica navedenih u tužbi. Zaključuje se i da je pitanje nedopuštenih raspolaganja stranaka u ZPP Crne Gore taksativno navedeno kao uvjet za donošenje presude zbog propuštanja, dok je odredbama naših procesnih zakona ovom pitanju posvećen poseban stav člana zakona. Zatim, zakonodavac je predvidio mogućnost odlaganja donošenja presude zbog propuštanja radi pribavljanja obavijesti vezanih uz pretpostavke za njezino donošenja, što također nije određeno procesnim zakonima u $\mathrm{BiH}$.

\subsection{Presuda zbog propuštanja u makedonskom parničnom postupku}

Institut presude zbog propuštanja $\mathrm{u}$ makedonskom pravu $^{112}$ propisan je odredbom čl. 319. Zakona o parničnom postupku Republike Makedonije. ${ }^{113}$ Ukoliko tuženik ne podnese odgovor na tužbu u roku od 30 dana, sud donosi presudu kojom usvaja tužbeni zahtjev ako su ispunjeni i sljedeći uvjeti: da je tuženom uredno dostavljena tužba i poziv za davanje odgovora na tužbu, da osnovanost tužbenog zahtjeva proizlazi iz činjenica navedenih u tužbi, da činjenice na kojima se zasniva tužbeni zahtjev nisu u suprotnosti s dokazima koje je tužitelj podnio ili s općepoznatim činjenicama i da ne postoje općepoznate okolnosti iz kojih proizlazi da je tuženi bio opravdano spriječen podnijeti odgovor na tužbu.

ZPP RM, kao i ZPP RH, ZPP RS i ZPP Crne Gore određuje da sud ovu presudu donosi po službenoj dužnosti, ali i da tužitelj može podnijeti prijedlog za njezino donošenje. Također, kao u ZPP-u RH, ZPP-u RS, ZPP-u Crne Gore kod materijalne pretpostavke za donošenje presude zbog propuštanja u ZPP-u RS zakonodavac je propisao da osnovanost zahtjeva proizlazi iz činjenica navedenih u tužbi.

112 Ova presuda u makedonskom zakonodavstvu nosi naziv „Presuda zbog nepodnošenja odgovora na tužbu“.

Službeni vijesnik Republike Makedonije, br. 79/05., 110/08., 83/09., 116/10. (dalje - ZPP $\mathrm{RM})$. 
Nadalje, kao u ZPP-u RH i ZPP-u RS, kao uvjet za njezino donošenje propisano je i da ne postoje općepoznate okolnosti iz kojih proizlazi da su tuženika spriječili opravdani razlozi da odgovori na tužbu.

\subsection{Presuda zbog propuštanja u slovenskom parničnom postupku}

U slovenskom pravu, sud će donijeti presudu kojom se usvaja tužbeni zahtjev ako tuženik ne odgovori na tužbu u roku od 30 dana, ako su ispunjeni sljedeći uvjeti: ako je tuženom uredno dostavljena tužba na odgovor, ako se ne radi o zahtjevu kojim stranke ne mogu raspolagati sukladno odredbi čl. 3. st. 3. ZPP SL, ako osnovanost tužbenog zahtjeva proizlazi iz činjenica koje su navedene u tužbi, ako činjenice na kojima se zasniva tužbeni zahtjev nisu u suprotnosti s dokazima koje je sam tužitelj podnio ili s općepoznatim činjenicama. ${ }^{114}$ Donošenje presude će se odgoditi ako je potrebno primiti obavijesti o okolnostima iz prethodno navedenog stava. Ako se osnovanost tužbe ne temelji na činjenicama navedenim u tužbi, sud će donijeti presudu kojom će odbiti tužbeni zahtjev. ${ }^{115}$

ZPP SL na identičan način kao i ZPP Crne Gore uređuje institut presude zbog propuštanja. I u ZPP-u SL je propisano da za donošenje ove presude nije potreban prijedlog tužitelja. Također, kao u ZPP-u RH, ZPP-u RS, ZPP-u Crne Gore i $\mathrm{ZPP}-\mathrm{u}$ RM kod materijalne pretpostavke za donošenje presude zbog propuštanja zakonodavac je propisao da osnovanost zahtjeva proizlazi iz činjenica navedenih u tužbi. Nadalje, pitanje nedopuštenih raspolaganja stranaka ZPP SL taksativno navodi kao uvjet za donošenje presude zbog propuštanja, jednako kao i ZPP Crne Gore, te predviđa i mogućnost odlaganja donošenja presude zbog propuštanja radi pribavljanja obavijesti vezanih uz pretpostavke za njezino donošenje.

\section{6. ALI (American Law Institute) / UNDROIT Principles of Transnational Civil Procedure}

ALI / UNDROIT Načela transnacionalnog građanskog postupka ${ }^{116}$ predstavljaju standarde za rješavanje transnacionalnih trgovačkih sporova, ali su primjenjiva i za rješavanje drugih vrsta građanskih sporova. Na početku postupka strankama mora biti upućena obavijest uz kopiju tužbe, u kojoj će biti navedene

114 Vidi čl. 318. st. 1. Zakona o parničnom postupku SL, Službene novine Republike Slovenije, br. 73/2007. od 13. 08. 2007. i 37/09. (dalje - ZPP SL)

115 Član 318. st. 2 i st. 3. ZPP SL.

ALI (American Law Institute) / UNDROIT Principles of Transnational Civil Procedure, www.unidroit.org. 
tvrdnje iz tužbe i navođenje tužbenog zahtjeva. Tužena strana mora biti obaviještena o pokretanju postupka radi podnošenja odgovora, kao i o mogućnosti donošenja presude zbog propuštanja zbog nepodnošenja odgovora (čl. 5. st. 1.). Tužba i priloženi dokazi podnose se na jeziku suda, ali isto tako i na jeziku države u kojoj osoba ima stalno prebivalište ili sjedište pravne osobe. Tuženi i druge stranke trebaju podnijeti odgovor na jeziku suda (čl. 5. st. 2.). Stranka treba imati pravednu priliku i razumno primjereno vrijeme da odgovori na činjenične i pravne tvrdnje i na dokaze koje je iznijela druga stranka, kao (i da odgovori) i na naloge i sugestije suda (čl. 5. st. 5.). Dužnost stranaka i njihovih odvjetnika je da se u postupanju prema sudu i drugim strankama ponašaju savjesno (u dobroj vjeri). One sa sudom dijele odgovornost za promicanje poštenog, učinkovitog i razumno brzog rješavanja postupka (čl. 11. st. 1. i 2.). Odvjetnici stranaka imaju profesionalnu obvezu da im pomažu u poštivanju njihovih proceduralnih obveza (čl. 11. st.5.).

Institut presude zbog propuštanja predviđen je u čl. 15. (Dissmissal and Default Judgment). Ona se donosi protiv tuženika ili druge stranke koja se, bez opravdanja, ne pojavi ili ne odgovori u propisanom roku (čl. 15. st. 2.). Uvjeti za njezino donošenje su: da postoji nadležnost nad strankom protiv koje se presuda treba donijeti, da su ispoštovane odredbe o obavijesti i da je stranka imala dovoljno vremena za odgovor, da je zahtjev razumno potkrijepljen dostupnim činjenicama i dokazima, te da je dozvoljen (čl. 15. st. 3.).

Stranke su obvezne sudjelovati u postupku. Nepoštivanje obveze sudjelovanja podliježe sankcijama. Tako sud može izreći sankcije strankama, odvjetnicima i trećim osobama zbog propusta ili odbijanja ispunjavanja obveza u postupku. Sankcije trebaju biti razumne i razmjerne ozbiljnosti predmetnog pitanja i uzrokovane štete, te odražavati opseg sudjelovanja i stupanj do kojeg je ponašanje bilo namjerno. Kao sankcije su predviđene: odbacivanje zahtjeva, obrana ili tvrdnji u cijelosti ili djelomično, izvođenje negativnih zaključaka, donošenje presude zbog propuštanja. Sankcije za stranke i osobe koje nisu stranke mogu biti i novčane sankcije, kao što su novčane kazne i obročne novčane kazne (astreintes).

\section{Zaključak}

S ciljem povećanja učinkovitosti suđenja, unaprijeđenja koncentracije u postupanju i prikupljanju procesne građe propisano je da je dostava tužbe i pozivanje tuženika da podnese odgovor na tužbu postao obvezan podstadij u fazi pripremanja glavne rasprave, dok je dostava odgovora na tužbu postala dužnost tuže- 
nika. Kao procesni institut odgovor na tužbu bio je normiran svakim zakonom o parničnom postupku koji je bio u primjeni na području BiH Grpp s određenim specifičnostima u odnosu na kasnija rješenja, zatim ZPP 58, ZPP 78, ZPP $98 \mathrm{~s}$ istovjetnim odredbama i Zakonom o parničnom postupku $\mathrm{F} \mathrm{BiH} \mathrm{iz} \mathrm{2003.} \mathrm{godine,}$ koji uvodi novine u ovaj institut. Tuženik se prilikom dostave tužbe na odgovor poučava o posljedicama nedostavljanja odgovora na tužbu - donošenje presude zbog propuštanja. Ova presuda bila je normirana Grpp, te je ponovo uvedena ZPP F BiH iz 2003. godine, kao jedna od mjera koja služi kao procesnopravno sredstvo za ubrzanje i djelotvornost parničnog postupka. Presuda zbog propuštanja javlja se kao mjera procesne discipline, a njezin zadatak je dvojak: poštivanje načela suđenja u razumnom roku i sankcioniranje pasivnog ponašanja tuženika tijekom postupka.

Komparacijom pravila u pravnim sustavima bivših jugoslovenskih republika s pravilima kojima je presuda zbog propuštanja regulirana u našem procesnom zakonodavstvu, dolazi se do zaključka da su uvjeti koji moraju biti ispunjeni za njezino donošenje slični onima koji su predviđeni našim procesnim zakonodavstvom, s time da postoje izvjesne razlike. Razlika se prije svega ogleda kod materijalnih pretpostavki za donošenje presude zbog propuštanja, tako da se u našim procesnim zakonima ova presuda neće donijeti ako je tužbeni zahtjev očito neosnovan odnosno kada je tužbeni zahtjev očito protivan činjenicama navedenim u tužbi. U zakonima o parničnom postupku u Hrvatskoj, Srbiji, Crnoj Gori i Sloveniji materijalna pretpostavka za donošenje presude zbog propuštanja je da osnovanost tužbenog zahtjeva proizlazi iz činjenica navedenih u tužbi. Dakle, u ovim je procesnim zakonima propisan stroži uvjet - sud treba utvrditi da, bez sumnje, osnovanost zahtjeva proizlazi iz činjenica tužbe, za razliku od naših procesnih zakona koji propisuju blaži uvjet - nepostojanje očite neosnovanosti zahtjeva. Mišljenja smo da su bolja rješenja ponuđena u citiranim zakonima. Nadalje, za razliku od ZPP RH, ZPP RS, ZPP RM, naši procesni zakoni, kao i ZPP Crne Gore i ZPP SL ne predviđaju kao uvjet za donošenje presude zbog propuštanja da ne postoje općepoznate okolnosti iz kojih proizlazi da su tuženog spriječili opravdani razlozi da odgovori na tužbu. Smatramo da su rješenja ponuđena u navedenim zakonima pozitivna jer je u praksi moguće da se pojave neke izvanredne okolnosti (npr. poplave, požari i druge nepogode) koje u konkretnom slučaju mogu predstavljati opravdan razlog koji je tuženika spriječio da dostavi odgovor u zakonom propisanom roku. Također, pitanje nedopuštenih raspolaganja stranaka u ZPP Crne Gore, ZPP SL formulirano je kao taksativno naveden uvjet za donošenje presude zbog propuštanja, dok je odredbama naših procesnih zakona, ZPP RS i ZPP HR ovom pitanju posvećen poseban stav člana zakona te je propisano da presuda zbog propuštanja neće biti donesena ako se radi o zahtjevi- 
KEVO, M., Pravne posljedice propuštanja odgovora na tužbu Zbornik radova Pravnog fakulteta Sveučilišta u Mostaru, br. XXVII., 2019., str. 84. - 120.

ma kojim stranke ne mogu raspolagati. Suštinski, riječ je o istom rješenju samo što su naši procesni zakoni, te ZPP RS i ZPP RH dali veći značaj tom uvjetu, što je po našem mišljenju ispravnije.

Posljednjom intervencijom zakonodavca i usvajanjem Izmjena ZPP F BiH odgovoreno je na brojne kritike koje je izazivalo ranije ponuđeno zakonsko rješenje prema kojem se presuda zbog propuštanja nije mogla pobijati djelotvornim pravnim lijekom već samo prijedlogom za povrat u prijašnje stanje, kao pravnim sredstvom. Odredbom čl. 30 Izmjena ZPP F BiH odnosno Izmjena ZPP RS brisana je odredba čl. 183., koja je izričito isključivala žalbu protiv presude zbog propuštanja i koja je prijedlog za povrat u prijašnje stanje predviđala kao jedino dopušteno pravno sredstvo protiv ove presude. Navedenim Izmjenama ZPP F $\mathrm{BiH}$ i ZPP RS kao osnovni redovni pravni lijek protiv presude zbog propuštanja uvedena je žalba. Odredbom čl. 33. Izmjena ZPP F BiH odnosno čl. 33. Izmjena ZPP RS u čl. 208. dodan je novi stav. 2. koji propisuje da se presuda zbog propuštanja ne može pobijati zbog pogrešno ili nepotpuno utvrđenog činjeničnog stanja. Na ovaj način presuda zbog propuštanja udovoljila je Ustavu F BiH i čl. 13. Konvencije, jer je omogućeno pravo na djelotvoran pravni lijek - žalbu.

Promatrajući u radu institut presude zbog propuštanja, odnosno pretpostavke za njezino donošenje javljaju se pitanja koja bi trebalo razmotriti. Iz odredbe čl. 182. st. 1. proizlazi da je za njezino donošenje potreban prijedlog tužitelja. U zakonu o parničnom postupku $\mathrm{F} \mathrm{BiH}$ de lege ferenda trebalo bi unijeti izmjenu da se iz čl. 182. st. 1. ukloni prijedlog tužitelja za donošenje presude zbog propuštanja, jer se ne vidi svrsihodnost takovog rješenja. Tužitelj nema pravni interes da se protivi donošenju presude zbog propuštanja, a ovakvo rješenje ne pridonosi ekonomičnosti i učinkovitosti postupka. Nadalje, iz odredbe čl. 182. st. 2. ZPP F BiH, odnosno ZPP RS, te ZPP BiH proizlazi da u situaciji kada su dokazi u tužbi samo predloženi, a ne i dostavljeni uz tužbu, sud ih treba uzeti u obzir i na temelju predloženih, a ne dostavljenih dokaza, donijeti presudu zbog propuštanja. Kao logično se nameće pitanje kako sud može provjeriti usklađenost činjenica, dokaza i tužbenog zahtjeva, ako pred sobom nema dokaze, barem one koji se mogu dostaviti uz tužbu - isprave, zapisnik o osiguranju dokaza i sl., već samo prijedloge dokaza odnosno njihov naziv, te je li za zaključak suda da tužbeni zahtjev nije očito neutemeljen dovoljan pasivan stav tuženika koji se tumači kao usuglašavanje s navodima protivnika? U zakonu o parničnom postupku $\mathrm{F} \mathrm{BiH}$ de lege ferenda trebalo bi unijeti izmjene u pogledu materijalne pretpostavke za njezino donošenje tako da osnovanost tužbenog zahtjeva proizlazi iz činjenica navedenih u tužbi, da činjenice na kojima se temelji tužbeni zahtjev nisu u protivnosti s dokazima koje je sam tužitelj podnio ili s činjenicama koje su općepoznate. Ovakve izmjene, gdje bi osnovanost zahtjeva bila izvjesna, pridonijele bi većoj pravnoj 
sigurnosti i sprječavanju mogućih zloupotreba. Nadalje, trebalo bi de lege ferenda unijeti izmjene da se po uzoru na ZPP BD propiše kao posebna pretpostavka za donošenje presude zbog propuštanja obveza tužitelja da uz tužbu dostavi dokaze koji se po svojoj prirodi mogu dostaviti. Jer samo u situaciji kada sud ima pred sobom dokaze navedene u tužbi, može kvalitetno provjeriti materijalno pravnu pretpostavku za donošenje presude zbog propuštanja i donijeti pravilnu odluku.

\section{LEGAL CONSEQUENCES OF FAILURE TO SUBMIT STATEMENT OF DEFENSE}

Summary: One of the many novelties brought by the Civil procedure Act of the Federation of Bosnia and Herzegovina from 2003, in order to increase the efficiency of the trial, is that the delivery of the lawsuit and summoning defendant to file a statement of defense has become a mandatory sub point at the stage of preparation of the main hearing, while the delivery of the statement of defense became the duty of the defendant. The court will deliver a copy of the lawsuit with its attachments to the defendant in order of filing a written statement of defense, and in the summons to court it will forewarn him to the legal consequences of failure to act. However, procedural law does not oblige any party to hold a particular court order, so the defendant can be active at his choice and take civil action, i.e. to oppose the prosecutor's request, acknowledge the factual allegations and demands of his opponent, or remain passi$v e$, that is defend himself by failing to take civil action in order to protect his interests.

The aim of this paper is to analyze the institute of the statement of defense, with special attention given to the failure of civil action for submitting a written statement of defense, which results in procedural decision - a default judgment, which accepts the claim without discussion and evidence. The legal nature of the default judgment is generally explored, possibility of accepting and the possibility of its rebuttal are considered. Historical development of it will be considered beforehand. It will also point to the solutions in a comparative law.

Key words: lawsuit, statement of defense, default judgment, request for the return to status quo ante, appeal 